US Army Corps of Engineers ${ }_{\circledast}$

Engineer Research and

Development Center

Coastal Inlets Research Program

\title{
Review of Coastal Tidal Inlet Morphodynamics in the Context of Barrier-Inlet Sustainability
}

Tanya M. Beck

August 2019

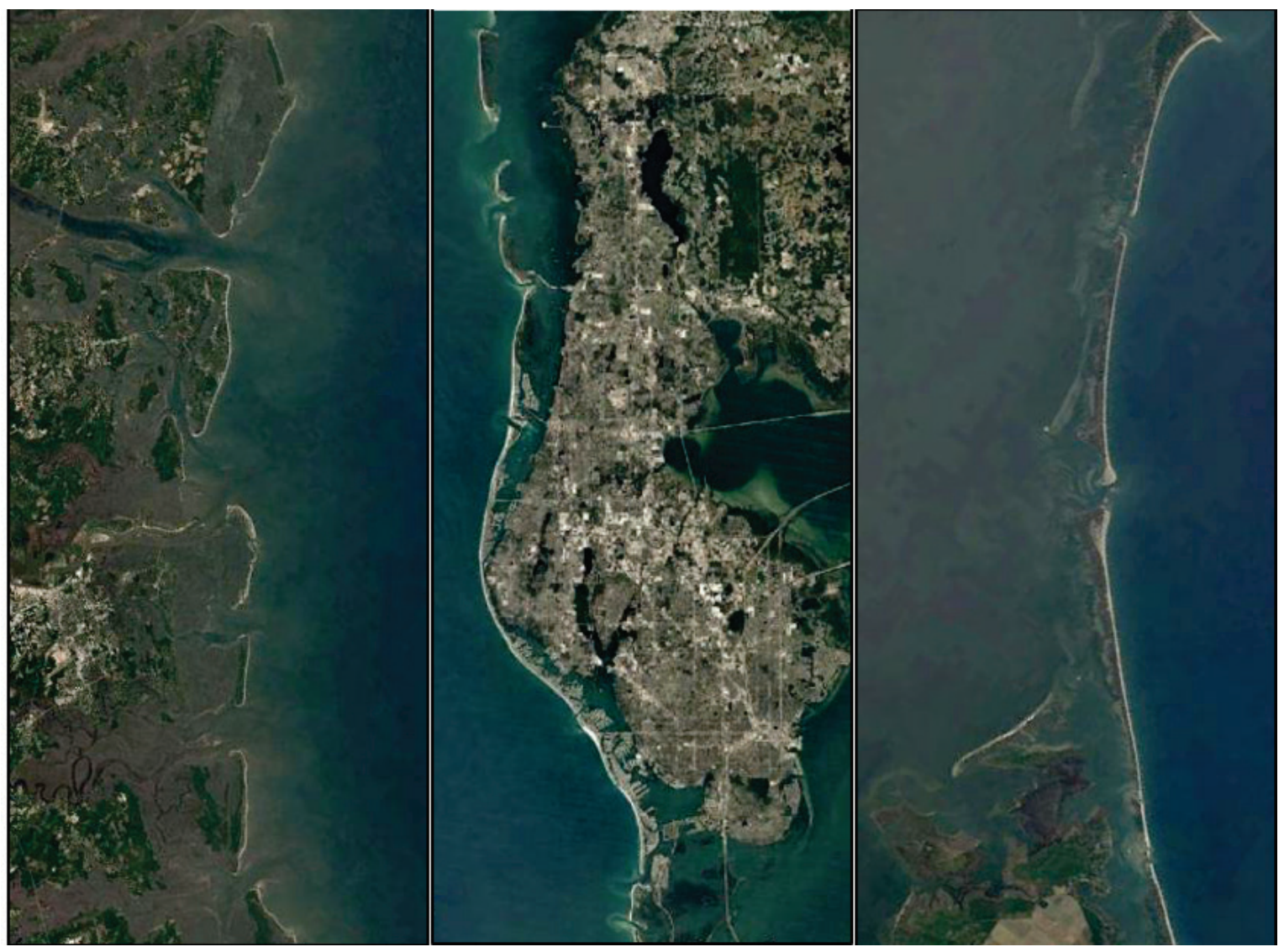


The U.S. Army Engineer Research and Development Center (ERDC) solves the nation's toughest engineering and environmental challenges. ERDC develops innovative solutions in civil and military engineering, geospatial sciences, water resources, and environmental sciences for the Army, the Department of Defense, civilian agencies, and our nation's public good. Find out more at www.erdc.usace.army.mil.

To search for other technical reports published by ERDC, visit the ERDC online library at http://acwc.sdp.sirsi.net/client/default.

Photos: Barrier-inlet systems of South Carolina-Georgia (left), west-central Florida (center), and the outer banks of North Carolina (right), U.S. Landsat images from Copernicus satellite (Google Earth 2018). 


\section{Review of Coastal Tidal Inlet Morphodynamics in the Context of Barrier-Inlet Sustainability}

Tanya M. Beck

Coastal and Hydraulics Laboratory

U.S. Army Engineer Research and Development Center

3909 Halls Ferry Road

Vicksburg, MS 39180-6199

Final report

Approved for public release; distribution is unlimited.

Prepared for U.S. Army Engineer Research and Development Center 3909 Halls Ferry Road

Vicksburg, MS 39180-6199

Under Project No. U4352920, Inlet Geomorphic Evolution Work Unit, "Guidance for Numerical Modeling of Navigation Inlet Mining Studies" 


\section{Abstract}

This Coastal and Hydraulics Engineering special report is a general overview of coastal tidal inlet morphodynamics, sediment management practices, and barrier-inlet system sustainability at long-term, regional scales. The focus of coastal tidal inlet morphodynamics in this report is on the primary managed resource, coastal littoral sediments, which are the primary substrate for coastal barrier islands and tidal inlet sediment systems. Management practices concerned with sustainability are discussed with a temporal focus on planning horizons of 50 to 100 years. Special considerations are offered on how past coastal zone management has evolved the understanding of natural and anthropogenically modified geomorphic features and how perspectives have changed with regards to the sustainability of management practices for these sediment systems. Over longer timescales, such as centuries, the impacts of eustatic sea-level rise, climate change (e.g., storm intensity and frequency), long-term crossshore and longshore sediment transport patterns, geologic isostacy and subsidence, and other important processes affect tidal inlet dynamics. Long-term studies conducted at regional spatial scales, including adjacent barriers and multiple inlets, are necessary to evaluate the cumulative effects of the aforementioned processes along with the effects of anthropogenic modifications, such as ebb-tidal delta mining and beach placement, to barrier-inlet sustainability.

DISCLAIMER: The contents of this report are not to be used for advertising, publication, or promotional purposes. Citation of trade names does not constitute an official endorsement or approval of the use of such commercial products. All product names and trademarks cited are the property of their respective owners. The findings of this report are not to be construed as an official Department of the Army position unless so designated by other authorized documents. 


\section{Contents}

Abstract...................................................................................................................................... if

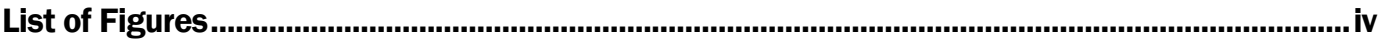

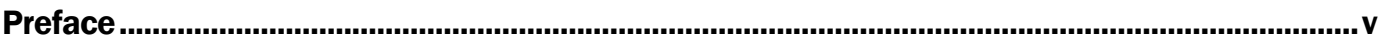

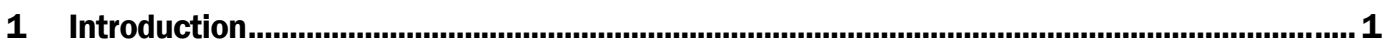

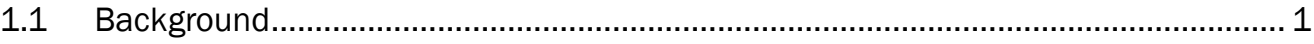

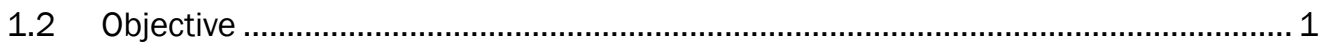

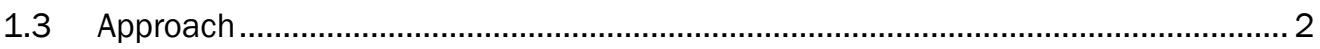

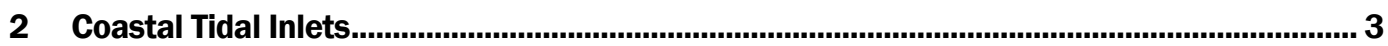

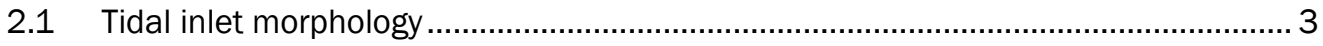

2.2 Sediment transport and tidal inlet bypassing.................................................... 6

2.3 Numerical investigations into barrier-inlet morphodynamics .................................. 11

3 Sediment Management at Tidal Inlets ..................................................................................14

3.1 Ebb-tidal delta volume .................................................................................... 14

3.2 Tidal inlet delta mining .............................................................................. 17

3.3 Sediment reservoir models........................................................................... 22

3.4 Regional sediment management (RSM) ...................................................... 25

4 Barrier-Inlet System Sustainability and Long-Term Management Perspectives .................. 31

4.1 Natural barrier-inlet development and evolution ................................................ 31

4.2 The effects of sea-level rise on inlet processes and long-term evolution of

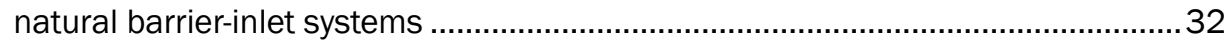

4.3 Anthropogenic effects: A focus on barrier-inlet systems of the United States ..........36

4.4 Long-term management of barrier-inlet systems ................................................ 37

4.4.1 Advancements in regional budgets of barrier-inlet systems in the United

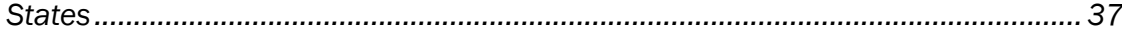

4.4.2 Future management for sustainable barrier-inlet systems ..................................... 39

5 Summary and Future Research Directions ...............................................................................42

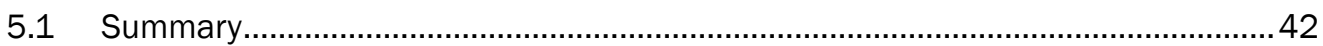

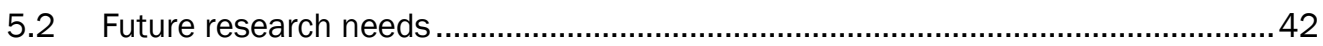

References...................................................................................................................................44

Unit Conversion Factors..............................................................................................................5

\section{Report Documentation Page}




\section{List of Figures}

Figure 1. Illustration of the various morphological features of an ebb-tidal delta (left) and the dominant tidal and wave-induced current and sediment transport pathways across a tidal inlet (right). (Modified from Davis and FitzGerald 2004).

Figure 2. Classification of barrier-inlet systems based upon their relative influence of tide and wave energy, represented here as mean tidal range and mean wave height, respectively (Davis and Hayes 1984).

Figure 3. Two generalized modes of sediment transport at tidal inlets first hypothesized by Bruun and Gerritsen (1958), bar bypassing and tide-induced bypassing, illustrated here as hypothesized pathways under the influence of tide- (green) and wave-induced (blue) transport at an idealized inlet.

Figure 4. Six classifications of dominant morphodynamics and sediment bypassing processes at natural tidal inlets (FitzGerald et al. 2000). The original models by FitzGerald were developed through analysis of time-series aerial photographs illustrating the positions of geomorphic features (e.g., shoals) as they become emergent and migrate across the inlet ebb-delta platform.

Figure 5. Three additional classifications of dominant morphodynamics and sediment bypassing processes at engineered tidal inlets (FitzGerald et al. 2000) in addition to those for natural inlet systems (Figure 3). Note that there is limited time-series representation of migration of geomorphic features such as shoals.

Figure 6. The IRM describing the net littoral drift ( $\left.Q_{\text {IN }}\right)$ into the ebb-tidal delta $\left(V_{E e}\right)$ and how each subsequent reservoir in the general sediment bypassing pathway captures a reduced quantity of sediment from its updrift reservoir (modified from Kraus [2000]).

Figure 7. Plan view and cross-sectional diagram of tidal inlet stratigraphy illustrating the sedimentology of a stable and migratory tidal inlet in a barrier-inlet system (from FitzGerald et al. [2008], originally developed by Pettijohn 1988). 


\section{Preface}

This study was conducted for the U.S. Army Engineer Research and Development Center (ERDC) under the U. S. Army Corps of Engineers Coastal Inlets Research Program, Project No. U4352920, Inlet Geomorphic Evolution Work Unit, "Guidance for Numerical Modeling of Navigation Inlet Mining Studies.” The technical monitor was Dr. Julie D. Rosati.

The work was performed by the Coastal Engineering Branch of the Navigation Division, ERDC, Coastal and Hydraulics Laboratory (CHL). At the time of publication of this report, Ms. Lauren Dunkin was Chief, Coastal Engineering Branch, and Dr. Jacqueline S. Pettway was Chief, Navigation Division; Mr. Charles E. Wiggins was the ERDC Technical Director for Civil Works and Navigation Research, Development, and Technology Transfer portfolio. The Deputy Director of ERDC-CHL was Mr. Jeffrey R. Eckstein, and the Director was Dr. Ty V. Wamsley.

The Commander of ERDC was COL Ivan P. Beckman, and the Director was Dr. David W. Pittman. 


\section{Introduction}

\subsection{Background}

Coastal tidal inlets are natural, dynamical channel features that separate barriers such as islands and headlands. Coastal barrier islands and tidal inlets are the land-sea interface along much of the Atlantic and Gulf of Mexico coastlines within the United States, and coastal tidal inlets serve as the primary connections between oceans and coastal estuaries. Owing to their geographic position along the coastline and functional navigability for waterborne vessels, these features are often densely populated and as a result, greatly modified by humans to meet the needs of navigation access between the interior and open waters. The morphodynamics of tidal inlets are often challenging to manage, and uncertainty in predicting their behavior is relatively high in comparison to other similar managed geomorphic features.

\subsection{Objective}

A review of tidal inlet morphodynamics is provided here in the context of long-term management practices necessary to maintain resilient coastal tidal inlets and their adjacent beaches and barriers. A resilient coastal tidal inlet is defined here as a hydraulically stable inlet (as defined by Escoffier [1940]) with active sediment bypassing between adjacent beaches characteristic of its inlet morphodynamics. The focus on tidal inlet morphodynamics in this report is on the managed littoral sediments, which are the primary substrate for coastal barrier islands and tidal inlet systems.

Sand management practices concerned with resource sustainability, or specifically maintained inlet shoal volumes, are discussed with a temporal focus on planning horizons of 50 to 100 years, as are typical in coastal inlet and beach management planning, as well as a regional spatial scope that integrates multiple geomorphic features into a system. Special considerations are offered on how past coastal zone management has evolved based on the understanding of the natural and anthropogenically modified geomorphic features and how perspectives have changed concerning the sustainability of management practices for these sediment systems. 


\subsection{Approach}

The report is divided into four sections reviewing coastal barrier-inlet systems and their sustainability. Chapter 1 gives a brief background and report orientation. Chapter 2 is a general review of coastal tidal inlets. Chapter 3 discusses common sediment management strategies for tidal inlets and the science behind the practice. Chapter 4 discusses barrierinlet system sustainability and perspectives on the long-term management of these geomorphic features. Finally, Chapter 5 summarizes the research findings detailed in this report and provides future research needs on the topic of barrier-inlet management. 


\section{Coastal Tidal Inlets}

Tidal inlet morphodynamics have been studied in detail since the 1950s, although their geomorphic contribution has been documented in the scientific and historical literature before the 1950s. Tidal hydraulics is the key driving force in maintaining tidal inlet stability and there are many publications on this topic (Bruun 1978; De Swart and Zimmermann 2009; van de Kreeke and Brouwer 2017). This review focuses on the morphodynamics and sediment processes along the coastal barrier-inlet system as they are critical to understanding natural and anthropogenically modified systems and future sustainability of these features given human interaction.

\subsection{Tidal inlet morphology}

Tidal inlets separate coastal barriers such as islands and headlands and serve as conduits for transporting sediment and water between embayments and oceans, seas, and other tidally influenced waterbodies. Tides and waves induce currents that transport sediment across-shore and alongshore. The influences of tides and waves vary spatially and temporally. Owing to the bidirectional tidal flow, tidal inlets often develop deltaic deposits on both the landward and ocean-side resulting in a floodtidal delta and ebb-tidal delta, respectively.

Figure 1 illustrates the various morphological features and tide- and waveinduced transport pathways across an ebb-tidal delta of a stable tidal inlet (Hayes 1975; Hayes and FitzGerald 2013). Ebb-tidal deltas typically have a main ebb channel, a terminal lobe outlining the distal portion of the delta platform, which may or may not include swash bars, and marginal flood channels that flank one or both sides of the inlet (Figure 1). Tide and waveinduced transport around the ebb-tidal delta generally follow the conceptual models outlined in Figure 1 (Davis and FitzGerald 2004) with wave-induced sediment transport occurring over the shallow platform of the delta and tidally-induced sediment transport occurring in the main ebb channel, flood marginal channels, and bay-side channels. 
Figure 1. Illustration of the various morphological features of an ebb-tidal delta (left) and the dominant tidal and wave-induced current and sediment transport pathways across a tidal inlet (right). (Modified from Davis and FitzGerald 2004).

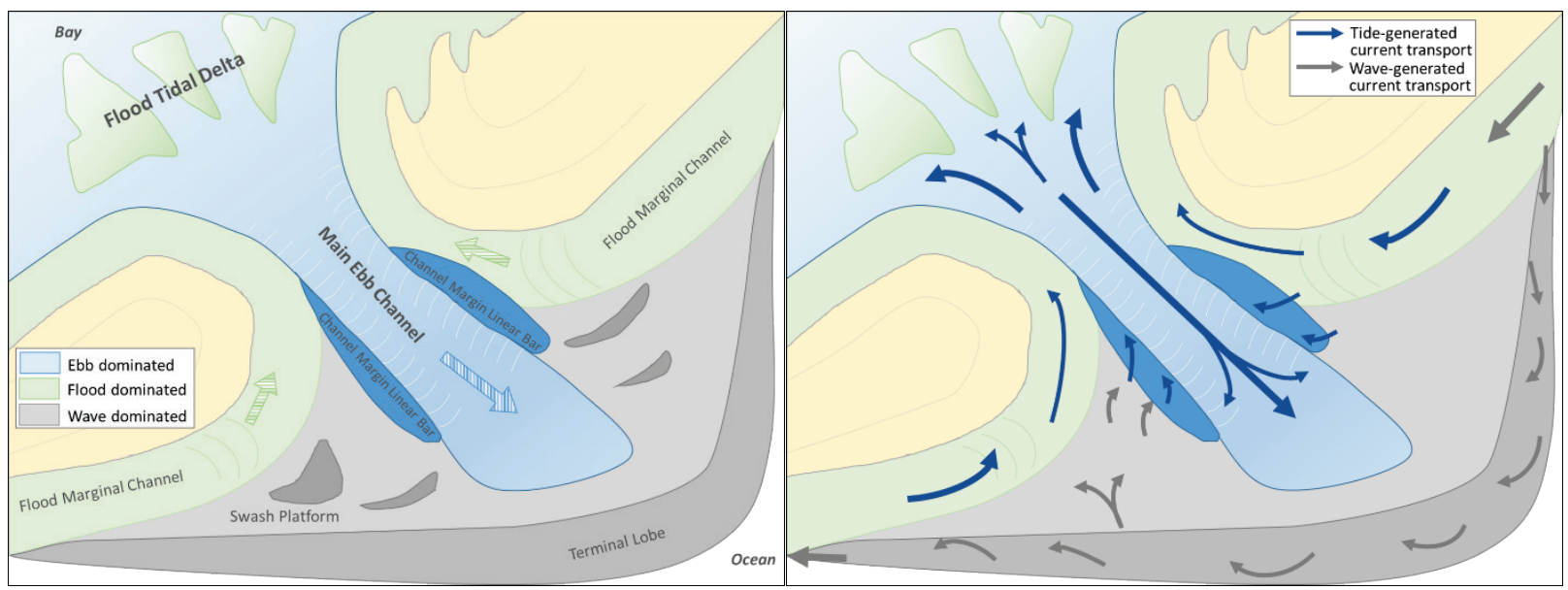

Barrier-inlet systems, comprised of one or more coastal barrier islands and tidal inlets, have been classified in terms of the dominant forcing that shapes the islands and the inlet (Davies 1964). Following this classification, Hayes (1979) and Davis and Hayes (1984) categorized the morphodynamics of barrier islands based on their tidal range to wave height (Figure 2). Hayes (1979) categorized the morphodynamics of barrier islands based on their tidal range within a medium wave energy regime (mean wave height of 0.60 to 1.5 meters $[\mathrm{m}]$ ) and found that microtidal coasts with a tidal range of o-2 $\mathrm{m}$ tend to have long and linear barrier islands and mesotidal coasts with a tidal range of 2-4 $\mathrm{m}$ tend to have shorter, characteristic drumstick-shaped barrier islands. Barrier islands do not occur along macrotidal coasts with tidal ranges greater than $4 \mathrm{~m}$. Hayes (1979) also determined that mesotidal barrier islands store large volumes of littoral sediment due to the unique combination of tide- to wave-forcing. Davis and Gibeaut (1990) furthered Hayes $(1979,1980)$ geomorphic classification of tide-dominated, wavedominated, and mixed-energy tidal inlets to include barrier-inlet systems with substantial offsets (Figure 3). 
Figure 2. Classification of barrier-inlet systems based upon their relative influence of tide and wave energy, represented here as mean tidal range and mean wave height, respectively (Davis and Hayes 1984).

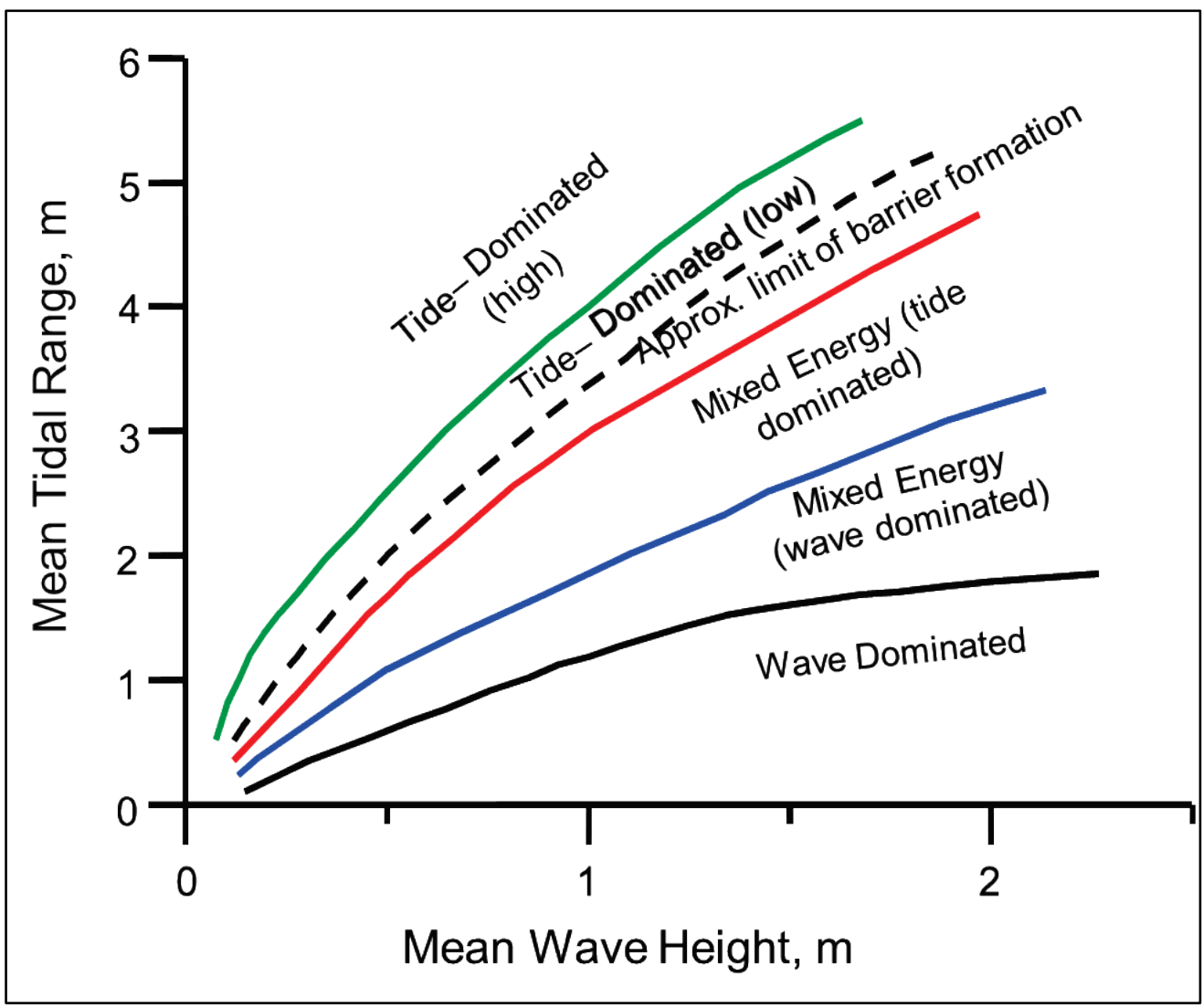

Davis and Hayes (1984) reviewed the various generalizations made about the classification of wave- vs. tide-dominated coasts with special references to tidal inlets and barrier islands and argued that this classification is most simplistically applicable to moderate wave energy coasts. They argued that there were too many factors, including physiography, tidal prism, riverine input, and the general availability of sediment, that influence the geomorphology of a barrier island and tidal inlet delta to characterize all barrier-inlet systems. They suggested that tidal prism may also be a better factor as opposed to tidal range; however, they cautioned against the use of further tidal or wave parameterization as a means of classification due to the various other influencing factors.

Sha and Van den Berg (1993) discussed the protrusion and orientation of ebb-tidal deltas along the West and East Frisian Islands and found that tidal prism played a significant role in the relative importance of wave to tidal forcing. They identified large ebb-tidal deltas as being updriftasymmetrical and smaller ebb-tidal deltas as downdrift-asymmetrical as 
related to the preferential position of the main inlet channel. Additionally, a rough estimate of protrusion to inlet width ratios illustrated a need to further investigate inlet widths and wave parameters beyond the square of significant wave height as a surrogate for general wave power. The work by Wang et al. (1995) illustrated the connection between a substantial width of an existing inlet and the development of two ebb-tidal deltas along the Dutch coastal tidal inlets under similar wave to tidal forcing.

Various parameters have been examined in terms of the morphologic shape of an ebb-tidal delta (Bruun 1978; Carr-Betts et al. 2012; Mehta et al. 1996; Powell et al. 2006; Walton and Adams 1976). Carr and Kraus (2001) discussed morphologic asymmetry of ebb-tidal deltas and channels with respect to channel maintenance and sediment bypassing capacity and argued that the asymmetry might be the result of orientation of the entrance channel and/or the flood-tidal delta and branching ebb channels within the bay. Further analysis by Carr-Betts et al. (2012) offer optimized empirical equations relating asymmetry of tidal inlets to tidal prism as a means of predictive capability for use in planning and design.

De Swart and Zimmermann (2009) reviewed the morphodynamics of tidal inlet systems with respect to the governing hydrodynamic processes of the various features of the systems. In their focus on ebb-tidal deltas, Oertel's (1988) and FitzGerald's (1996) conclusions on the dominant littoral drift direction influencing the downdrift orientation the main ebb channel of a tidal inlet was compared with counter examples from the German and Dutch coasts that demonstrate ebb channels with updrift orientations. Sha (1989) and Sha and van den Berg (1993) identified a phase lag between shore-parallel tidal currents and inlet-related tidal currents as the primary cause of updrift oriented inlet channels. This distinction is particularly valuable in the management of unstable inlets with concerns for the stability of a navigable main channel. Further, Sha (1989) and others (Cayocca 2001; Siegleet al. 2004) concluded that tidal currents alone were not solely responsible for cyclical ebb-tidal delta bypassing behavior, a reflection upon the importance of wave- and tidal-processes and their contribution to overall morphodynamics through interaction.

\subsection{Sediment transport and tidal inlet bypassing}

Sediment transport at tidal inlets is driven generally by a combination of tidal and wave energy mobilizing and transporting sediments. Past studies have investigated the general modes of sediment transport at distinct 
morphological features such as the balance between wave-induced alongshore transport along the adjacent beaches and around the outer lobe of the ebb-tidal delta and tide-induced through the inlet throat (Bruun and Gerritsen 1958). These two dominant sediment transport modes are represented as that shown in Figure 3, which assumes that sediment transport across the outer lobe of an ebb-tidal delta is dominated by wave processes, or bar-bypassing, and interior transport near the inlet throat is dominated by tidal processes.

Figure 3. Two generalized modes of sediment transport at tidal inlets first hypothesized by Bruun and Gerritsen (1958), bar bypassing and tide-induced bypassing, illustrated here as hypothesized pathways under the influence of tide- (green) and wave-induced (blue) transport at an idealized inlet.

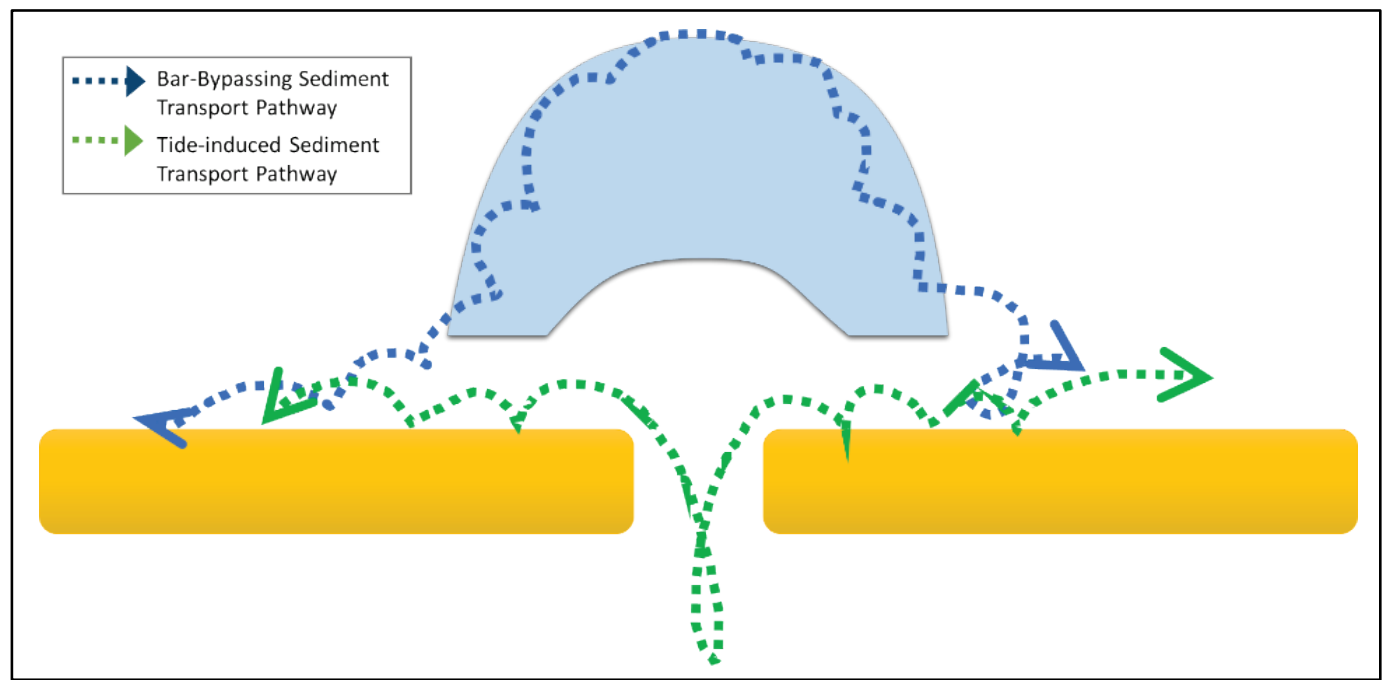

Larson and Kraus (2001) investigated the capacity of wave-induced suspended sediments being transported from the updrift to the downdrift sides of a tidal inlet. They developed a model of the distance of transport of fine sand particles suspended in the shallow nearshore waves as they entered a deeper, jettied-inlet channel. Neglecting tidal circulation (i.e., assuming slack tide) and upward diffusion by turbulence, they found that a suspended 0.17 millimeter $(\mathrm{mm})$ sand particle could travel at the most $20 \mathrm{~m}$ given mild, average wave conditions. They concluded that sediment entering the vicinity of an inlet through wave-induced current would settle within the inlet channel prior to reaching other side of the inlet. Oertel (1988) described the processes by which sediment is exchanged at tidal inlets over tidal cycles in combination with wave-induced littoral drift. Channel infilling generally occurs during slack tide whereas flooding tides are optimal for spit accretion and ebbing tides are optimal for accumulation over the ebb-tidal delta. 
Kana et al. (1999) reviewed the state of knowledge on tidal inlet sediment transport and bypassing models and related them to known processes at mixed energy tidal inlets. They reasoned, counter to Bruun and Gerritsen (1959), that for littoral transport to cross large or deep inlets that are more tidally dominated, the bypassing route must be inherently circuitous and that the greatest amount of transport occurs episodically through shoal bypassing. For many mixed energy inlets along the South Carolina and Georgia coasts, they defined a conceptual model for the partitioning of sediment transport and resultant morphologic change across an ebb-tidal delta and determined that approximately half of the volume of sediment in a bypassing shoal will move downdrift of the inlet after attachment to the shoreline.

Sexton and Hayes (1982) analyzed the volumetric change and morphodynamics of a bar-bypassing event at the mixed energy Captain Sam's Inlet, South Carolina, and found that the bypassed sediment totaled approximately 50,000 cubic meters $\left(\mathrm{m}^{3}\right)$. The event was initiated by the passage of a hurricane, and migration and attachment occurred over a timeframe of 6-12 months. There were not any significant changes to the main inlet throat cross-sectional area or tidal prism indicating that the inlet remained stable through the bypassing process. Also, multiple secondary channel formation and abandonment events promoted the extension and ultimately onshore migration of the downdrift bypassing bar.

FitzGerald et al. (2000) summarized sediment bypassing mechanisms for natural and engineered tidal inlets. They identified six models for natural inlets (Figure 4) and three for jettied inlets (Figure 5), noting that all unstructured inlets had some form of bypassing of volumes of sand on the order of 50,000 to more than $200,000 \mathrm{~m}^{3}$ on the order of 4 to 10 years. Some baseline level of continuous sand bypassing occurs at all tidal inlets; however, the magnitude and transport patterns at jettied inlets are less well understood and more viable depending on the design of the structures and if a channel is maintained, dredging characteristics. 
Figure 4. Six classifications of dominant morphodynamics and sediment bypassing processes at natural tidal inlets (FitzGerald et al. 2000). The original models by FitzGerald were developed through analysis of time-series aerial photographs illustrating the positions of geomorphic features (e.g., shoals) as they become emergent and migrate across the inlet ebb-delta platform.

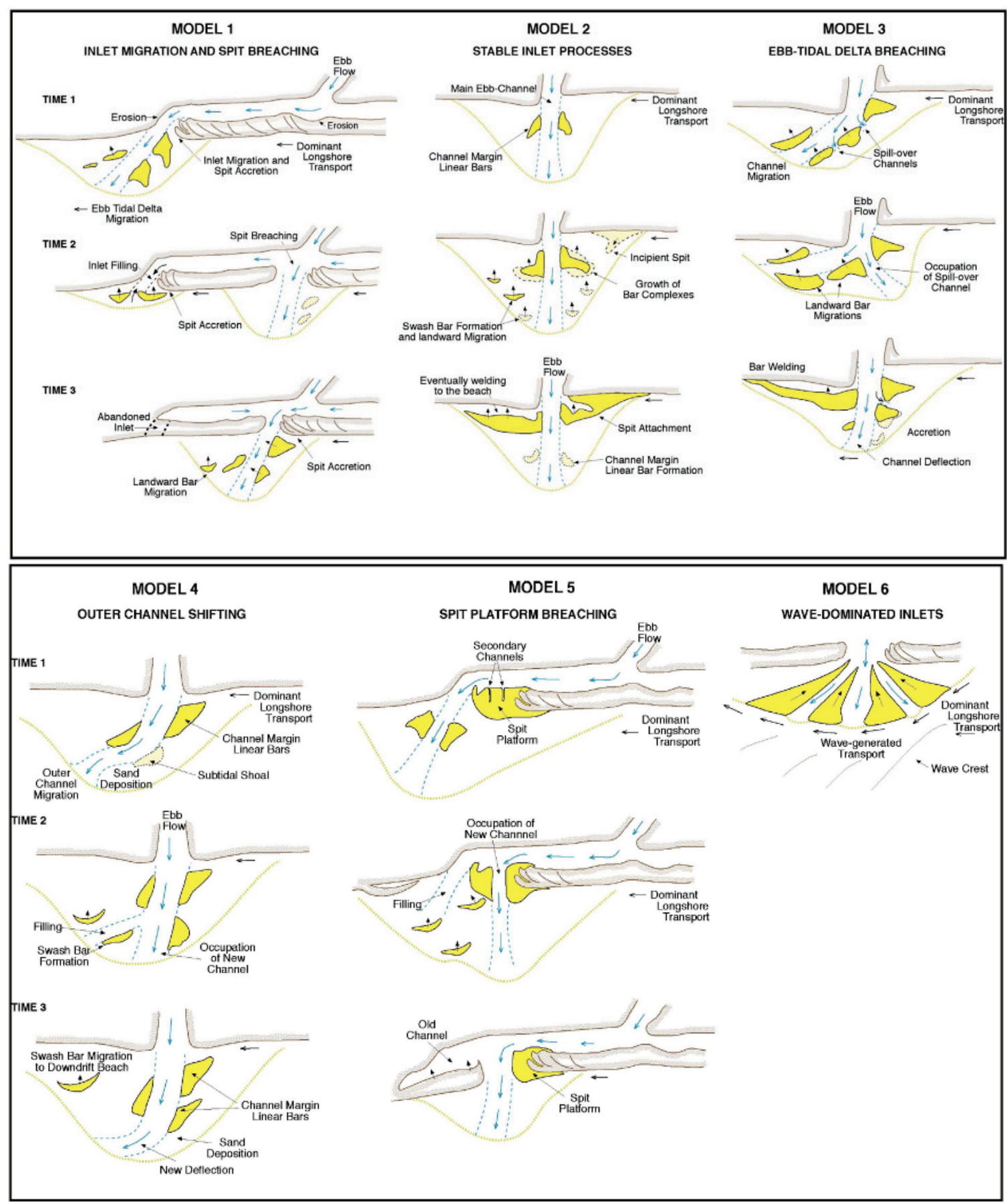


Figure 5. Three additional classifications of dominant morphodynamics and sediment bypassing processes at engineered tidal inlets (FitzGerald et al. 2000) in addition to those for natural inlet systems (Figure 3). Note that there is limited time-series representation of migration of geomorphic features such as shoals.

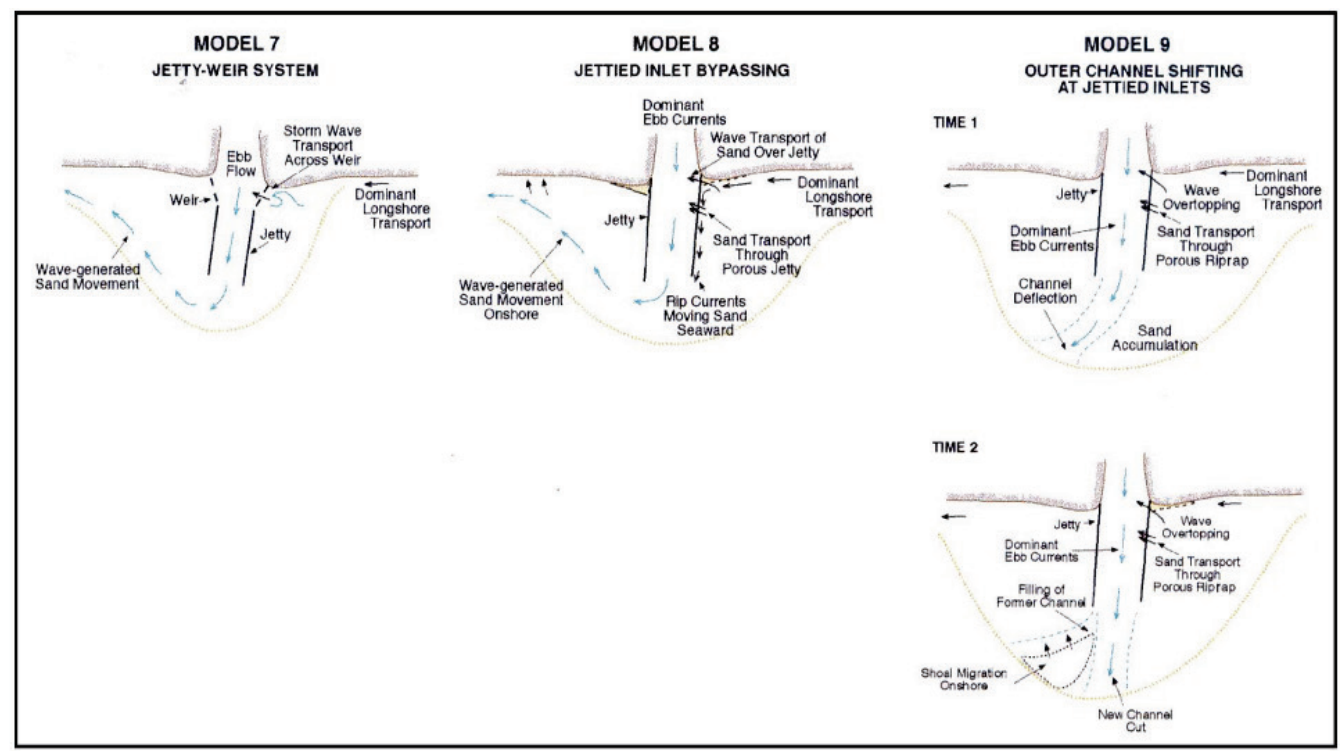

Price (1951) discussed the natural asymmetrical orientation of tidal inlets in Texas to be the result of their southerly position relative to the embayment, strong northerly winds funneling water over long fetches, the southward migration, the bearing of the barrier island, and a strong littoral drift along the ocean side. In his study, he argued that a reorientation of a navigation channel through these inlets toward the natural southerly orientation would potentially reduce channel sedimentation and possibly be well flushed under wind events that drive strong southerly flow out of the inlets.

Similar to Price (1951), Carr and Kraus (2001) suggested that aligning a navigation channel in a "preferred location and alignment" might reduce dredging maintenance costs; however, they cautioned that attention must be made toward the alignment with respects to predominant wave direction for favorable navigability. Based on an analysis of historical channels and asymmetric realignments of jetty structures, Bruun (1987) argued that reorientation towards the downdrift direction does not inhibit sedimentation within the channel and that it may cause navigational safety issues for some vessels due to the potential for wave reflection.

Tidal inlets redirect littoral sediment through complicated bypassing systems and store substantial volumes of sediment within their shoals dependent upon the ratio of wave- to tide-energy. In addition to this 
exchange between inlet geomorphic features and beaches along the open coast, there is also sediment exchange between the estuary an inlet serves and the ocean. Tidal hydraulics play a significant role in the net exchange of sediments between the ocean and estuary (DiLorenzo 1988; Speer and Aubrey 1985), as do basin hypsometry, riverine input, vegetation, and other landform geomorphologic processes (Wang et al. 2007).

Studies on the relative dominance of ebb versus flood forcing on sediment exchange at tidal inlets have focused on the tidal distortion as related to a mean set-up of basin sea levels for ebb-dominant systems or a mean setdown for flood-dominated systems (DiLorenzo 1988; Aubrey and Speer 1985; Speer and Aubrey 1985). Aubrey and Friedrichs (1988) found that the non-linear tidal response to changes in the tidal amplitude to basin depth ratio are strongly dependent upon the areal extent of intertidal flats within the basin. Essentially, tidal inlet systems that do not have extensive tidal flats tend to be flood-dominant systems, and that extensive tidal flats tended to be ebb-dominant systems.

An implication for these findings is that relative sea level changes may induce a change in tidal distortion near the inlet to the relative depth of the basin and tidal deltas and therefore impart a change in net sediment transport into or out of the basin. As sea level rises, and the tidal amplitude to basin depth ratio decreases, tidal distortion results in more flood dominance where there are extensive tidal flats.

\subsection{Numerical investigations into barrier-inlet morphodynamics}

Recent advances in numerical simulations of tidal inlet morphodynamics have improved the understanding on the exchanges between ocean and estuary, as well as tidal inlet geomorphic features and the adjacent coastline. The advent of two-dimensional (2D) and three-dimensional $\left.{ }_{3} \mathrm{D}\right)$ numerical modeling has improved predictive capabilities to evaluate longer time horizons (decades to centuries) for both idealized and realistic cases. The capability to run a matrix of hydrodynamic forcing, sediment properties, and geomorphic parameters allows for the exploration of the change in morphodynamics across a range of influential parameters (Dissanayake et al. 2011; Ridderinkhof et al. 2014; Styles et al. 2016; van der Wegen 2013).

In Elias et al. (2006), an in-depth analysis on the morphodynamics of Texel Inlet in the Dutch Wadden Sea through field measurements and 
numerical modeling revealed sediment transport patterns and resultant sediment budget for the inlet system. In their analysis of multibeam bathymetry-derived morphology, slip-face orientations of bedforms indicated dominant direction of flow, particularly for bedforms larger than $0.5 \mathrm{~m}$ in height with greater than $50 \mathrm{~m}$ wave lengths (sand waves and large megaripples or dunes). Resultant transport patterns over the ebb-tidal delta indicated cyclical patterns of transport due to ebb or flood dominance in different channels or platforms, with typical flood dominance in flood marginal channels and ebb dominance in the main ebb channel. Numerical analysis supported many previous findings about the flood dominance, sediment transport into the basin, and dominant flow patterns across the various features of a tidal inlet and ebb-tidal delta.

Dissanayake et al. (2009) tested various inlet widths, tidal asymmetry and propagation direction, and basin orientation using a 2D numerical model to determine their effects on the position of the main channel and the orientation of the ebb-tidal delta. They found that the direction of the tidal propagation determined the orientation of the ebb-tidal delta and that the basin orientation did not modulate the main channel position or asymmetric shape of the ebb-tidal delta. Ridderinkhof et al. (2014) investigated the dependence of ebb-tidal delta volume and basin length and symmetry and found a correlation similar to that of general tidal prism as a function of basin area. Varying basin lengths also adjusts the phase difference between alongshore and cross-shore tidal velocities, thereby influencing the symmetry of the main channel and ebb-tidal delta.

Wang et al. (2014) examined currents, sediment transport and long-term channel stability in a tidal inlet to a riverine estuary and found correlation between the tidal asymmetry and cyclical sediment transport among morphological cells. Ridderinkhof et al. (2016) conducted numerical simulations of shoal migration initiated from various channel cuts through the ebb-tidal delta of an idealized inlet to evaluate the growth and migration rate of a shoal under varying wave and tidal prism conditions. They found that there are thresholds for shoal formation and that the shoal migration speed increases with wave energy and decreases with tidal prism.

The potential closure of a tidal inlet has produced several numerical studies to evaluate the dominant forcing on this process. In Ranasinghe and Pattiaratchi (2003), the causes and effects of seasonal closure of tidal inlets were related to the wave energy influence on cross-shore processes 
by using the Dean's (1973) criteria. They determined that variability of alongshore transport to be the dominant process involved in inlet closure, but in areas of low longshore transport, stronger onshore transport tends to close tidal inlets whereas offshore transport helps to keep the inlet open.

Bertin et al. (2013) analyzed the various processes that play a role in the development of a wave-dominated inlet in fair weather conditions and their subsequent closure. Through calibrated models of wave-dominated seasonal inlets, they found that tidal asymmetry assisted in inlet breaching and that closure was affected by direct wave forcing, lateral barotropic pressure gradients that accelerate alongshore currents into the inlet, wave blocking during ebb tide, and a seasonal rise in sea level.

Nahon et al. (2012) and Dastgheib (2012) simulated the morphodynamic behaviors as those conceptually devised originally by FitzGerald (1988) and later modified by FitzGerald et al. (2000) with variable wave forcing, tidal range, and tidal prism. Both studies similarly found that although the general relationships defining the sediment bypassing behavior at a tidal inlet could be simulated, there were a number of other parameters that could be tested to better represent the variety of morphodynamics found in nature, including the seasonality of the wave climate and anthropogenic modifications to the tidal inlet.

In review of hydrodynamic observations across the multi-inlet system of the Rio Formosa, Pacheco et al. (2010) found that the availability of sediment stored in the ebb-tidal delta played a critical role in affecting instability and closure of the tidal inlets in a multi-inlet system. The focus on the stability of the ebb-tidal delta in this multi-inlet system pointed towards a need for further understanding of thresholds of change for tidal shoals in management of multi-inlet systems. 


\section{Sediment Management at Tidal Inlets}

Tidal inlets between sandy barrier islands are associated with dynamic and complex adjacent shorelines in contrast to the relatively straight and stable shorelines along the majority of the barrier islands. Complex shoreline processes are closely related to the bypassing mechanisms of the tidal inlet, as demonstrated by studies on the onshore migration of large-scale, complex shoals (Sexton and Hayes 1982). Dean (1990) analyzed beach erosion trends along the Atlantic coast of Florida and attributed nearly $85 \%$ of beach erosion to tidal inlet processes and anthropogenic impacts to these systems (e.g., dredging or coastal structures). Engineering of the inlets through hard structures and soft engineering practices, such as dredging and beach/nearshore placement, is a common approach to mitigate against coastal erosion (Bruun and Gerritsen 2005; Dean 1988 1993; Dean and Work 1993). There have been extensive studies conducted on quantifying the total volumes of littoral sediment contained within tidal inlet systems and their application in sediment-based reconstruction and nourishment practice (Beck and Legault 2012; Bruun and Gerritsen 2005; Douglas et al. 2003; Finkl et al. 2006; Fontolan et al. 2007; Houston 2017; Houston and Dean 2016; Oost et al. 2014; Schrader et al. 2016).

Sediment management at tidal inlets focuses on morphodynamics of the net depositional features, or sediment sinks: the ebb- and flood-tidal deltas, interior spits, breach washover deposits, and depressional features near the channel such as relic inlet channels. These features serve to trap and store littorally transported sediments, and they can serve as potential sources in an interconnected regional sediment system. More recently, the need to plan these types of soft engineering activities in the context of a region has motivated studies at larger regional scales (10s to 100 s of kilometers $[\mathrm{km}]$ ) and longer temporal scales (50-100 years) (Schrader et al. 2016). Yet, local and regional inlet sediment dynamics remain poorly understood, especially with regard to engineered systems. Ongoing management decisions must maximize beach preservation while conserving limited sediment resources to meet sediment management objectives for barrier-inlet systems.

\subsection{Ebb-tidal delta volume}

Ebb-tidal deltas are the key morphological features of coastal tidal inlets as they represent the most dynamical, depositional feature of concern to 
coastal managers. Fontolan et al. (2007) summarized this in their study on the sediment storage capacity and sand management strategies of northern Adriatic tidal inlets: "(1) they represent huge sand reservoirs, (2) sand shoals associated with ebb-tidal deltas reduce wave energy on landward beaches, and (3) they affect the bypass process towards downdrift shorelines." The development of a "no-delta bathymetry," for comparison with positive volumes attributed to ebb-tidal delta accumulations, is the most critical procedure of shoal volume calculations (Fontolan et al. 2007; Hicks and Hume 1996, 1997; Stauble 1998).

Dean and Walton (1975) developed a methodology to calculate the sand volume stored within ebb-tidal deltas through the creation of a relatively subjective "no-inlet" bathymetric surface, or baseline, and subtraction of measured bathymetry from that baseline. They correlated the ability to trap sediments within these inlet geomorphic features as related to the tidal range and estuary plan area, essentially tidal prism, with some suggestions about the relative influence of wave energy and direction. Walton and Adams (1976) correlated these volumes to tidal prism, for which they argued as being the dominant process maintaining a delta feature oceanward of a tidal inlet. Inlet tidal shoals are influenced by waves, tides, and other coastal forcing, and therefore, they arrived at three separate empirical equations with varying coefficients for the three coastlines of the United States, which have varying degrees of wave energy. Other parameters they suggested as influential were the wave-induced alongshore energy and grain size distribution of the littoral zone and inletbay system sediments. Concerning tidal prism to equilibrium feature concepts, Oertel (1988) argued that these empirically derived relationships were more suited to tidally dominated inlets with correlation of nine such inlets' ebb-tidal delta volume to tidal prism.

Hicks and Hume $(1996,1997)$ evaluated the ebb-tidal delta volumes of New Zealand's tidal inlets using this methodology and characterized the inlet type based on its orientation relative to the shoreline, shape, and geographic relationship to an adjacent headland feature. They found that wave energy did tend to decrease the overall volume of an ebb-tidal delta and that dominance in net littoral drift may be associated with a higher trapping capacity on the updrift side ebb-tidal deltas, leading to implications on the management of the adjacent main ebb channel. Additionally, management considerations on the effects of human-induced changes to tidal prism, and the potential tidal prism increase from basin 
area expansion under relative sea-level rise, should include the increased trapping potential of littoral sediments in a growing ebb-tidal delta, which may induce local and regional importation of littoral sediments.

Stauble (1998) reviewed three techniques used in the quantification of ebb-tidal delta volume computations: Ebb-Shoal Edge Method, Difference Map Method, and the Residual Method. All computations are made with gridded bathymetric data. The Edge method essentially computes volumes above a plane, the Difference method computes differences between all surveys and one initial bathymetry, and the Residual method based on the Dean and Walton (1975) approach computes differences from a "no-inlet bathymetry" that is based on an average or equilibrium beach profile taken from adjacent, representative bathymetry. The Edge method will typically provide the largest values dependent upon selection of a depth contour lower than all potential elevations of the inlet throat and ebb-tidal delta, and the Residual method was the most conservative approach with the smallest calculated values. Stauble (1998) did not discuss the intricate and nuanced volumetric inclusions through the bounding areas but did caution that the bounding boxes may change due to larger geomorphic dynamics not seen in specifically analyzed time periods.

Fontolan et al. (2007) developed a new semi-automatic geostatistical procedure to process ebb-tidal delta volumes for their study on the sediment storage capacity and sand management strategies for northern Adriatic tidal inlets. In their study, they used a rectangular boundary from the inlet throat to some distance offshore of the ebb-tidal delta extent and extended updrift and downdrift to lateral profiles that were "not affected by the ebb-delta structure," and then they generated a polynomial trend of the surface based on the entire ebb-delta dataset. This is in contrast to Dean and Walton (1975) and other previous methods as it reduces the amount of manual error in interpolations of "no-delta lateral profiles" across offset barrier islands. Polynomial trends to the third order tended to result in less negative volumes computed for the offshore area, and therefore, positive volume changes were the result of ebb-delta accumulations above the regional trend. Fontolan et al. (2007) argue that a more consistent regional trend provides an unbiased representation of volume and that representative volume should comprise the positive accumulation above that regional trend, even if the regional trend was attributed to the historical inlet morphodynamics. 
The methodology by Fontolan et al. (2007) does not consider time-series computations of ebb-tidal delta volume at inlets that have changed substantially over medium- to long-term timescales, and particularly those that have been stabilized by structures that can greatly modulate the nearshore bathymetry. Caution is suggested with regards to newly stabilized inlets with jetties and adjacent fillet development, which will trap a considerable quantity of sediment that would otherwise contribute to ebb-tidal delta development. At different stages of development, volumes contained in fillets or attachment locations may be considered closely connected reservoirs in a tidal inlet shoal accumulation (Kraus 2000; Legault et al. 2012), and a critical component to any volume change analysis must consider this geomorphological interpretation.

Powell et al. (2006) provide a comprehensive review of empirical morphodynamic relationships of tidal inlet cross-section area and ebband flood-tidal delta volume to tidal prism using 67 sandy barrier island inlets from Florida for reference. They determined that morphodynamic relationships were useful for prediction of changes in tidal inlet morphology on timescales consistent with equilibration (decades to centuries). One general principle identified is that the equilibrium ebbtidal delta volume is approximately one-fifth of the spring tidal prism.

\subsection{Tidal inlet delta mining}

Dean and Walton (1975) computed the volume of 23 ebb-tidal deltas of tidal inlets in Florida (United States) comprising a total of 306 million m ${ }^{3}$ (400 million cubic yards [yd3]) of material and concluded that there was enough sand in the shoals to meet the needs of $1,609 \mathrm{~km}$ (1,000 miles) of beach eroding at a rate of $1.5 \mathrm{~m}^{3}$ per meter ( $2 \mathrm{yd}^{3}$ ) per year for approximately 76 years. Their conclusion did not state that this was a short- or long-term solution but merely that the sand was of quality, littorally derived material and that it would meet those needs for a period of time. It also did not relate the removal of shoal volume to beach erosion, a now well-described phenomena (Dean 1990), and that rates may increase as material is removed for beach nourishment.

Dombrowski and Mehta (1996) conducted an analytical experiment to isolate the contributing parameters that affect ebb-tidal delta volume and growth. They found that three parameters had a significant effect on the growth of ebb-tidal deltas towards their equilibrium volume: suspended sediment concentration, sediment grain size, and deep water wave heights. 
Increases in suspended sediment concentrations were found to be correlated to an increase in growth rates, and more wave energy mobilizing sediment was found to be correlated to slower growth rates and decreasing ebb-tidal delta sizes. Interestingly, increasing grain size was found to be correlated to increasing ebb-tidal delta equilibrium volumes and their growth rates. Additionally, a wave-to-tidal energy ratio was developed to describe the relative impact of littoral-derived sediment mobility and deposition potential on the ebb-tidal delta. The larger the deep water waves, the less sediment can deposit and build the ebb-tidal delta volume.

A motive of the Dombrowski and Mehta (1996) study on ebb-tidal delta growth rates was to obtain an understanding of the processes occurring at the ebb delta in terms of deposition to assess how these processes affect ebb delta mining. To further this effort, Mehta et al. (1996) developed a simple cross-shore model to explain delta growth based upon an analysis of bottom shear stress from current and wave influence $\left(\mathrm{T}_{\mathrm{b}}\right)$ and the critical stress for scour ( $\mathrm{T}_{\mathrm{cr}}$ ), where deposition occurs for $\mathrm{T}_{\mathrm{b}}<<\mathrm{T}_{\mathrm{cr}}$ until they are approximately equal and there is no further deposition (e.g., the delta reaches an equilibrium volume). Then, they examined four Florida entrances to compare ebb-tidal delta growth curves to the measured ebb volumes and presented example ebb-tidal delta operational information from seven inlets in Florida, four in South Carolina, and three in New Jersey. Based upon their observations, they discussed several considerations in mining site selection criteria:

- The quantity of available sediment (above the adjacent bathymetric profile) and its proximity to its placement location are primary criteria for site selection, followed by sediment compatibility and physical and ecological impacts of the project.

- The two primary concerns for physical impacts are the rate of sediment replenishment of the ebb-tidal delta and the potential effects to adjacent beaches through modified waves and tidal currents.

- A delineation of the active, wave-induced transport zone, and passive, or tidally induced transport zone, areas (from (Mehta and Montague 1991) of the ebb-tidal delta are critical to predicting potential physical impacts.

- Moreover, the role of alongshore sediment transport in deposition at mining sites along the active and passive zones is still not well understood. 
For dredged inlets, Walther and Douglas (1993) developed a simplified inlet model where the delta growth rates were based primarily on the capacity of the inlet's dredged channel to trap sediment transported through tidally induced sediment transport across the ebb-tidal delta. This model was based on the assumption that the ebb jet currents transport a fixed rate of sediment volume evenly over the dredged area, and essentially equated deeper cuts as proportionally larger traps. The results of their comparison to three different ebb-tidal delta mining projects verified their model, with variances attributed to the relative rate of contribution of alongshore-driven sediment transport. The effects of the planform area and interconnectivity to adjacent beaches were largely ignored in this study, although they did caution that engineering activities of this kind should investigate the potential for increased erosion at adjacent beaches. Trudnack's (1997) physical modeling study demonstrated that mining of ebb tidal deltas do in fact increase local beach erosion rates and channel shoaling within an inlet.

Cleary and FitzGerald (2003) analyzed dredging-induced tidal prism changes and resultant sedimentation at Mason Inlet, North Carolina, and found that inlet relocation and basin dredging increased tidal prism substantially, reducing prism at adjacent barrier inlets connected through the Atlantic Intracoastal Waterway. Additionally, relic ebb-tidal delta material was noted as having migrated onshore, providing substantial nourishment for years to decades thereafter. Tidal current measurements indicated a flood dominance at the wave-dominated inlet, contributing to substantial interior shoaling and downdrift migration of the inlet.

Welsh and Cleary (2007) reviewed the results of a relocated, migratory, flood-dominated, and unstructured inlet in North Carolina and found that maintenance of the inlet's feeder channels will aid in maintaining the requisite tidal prism and flushing capacity to attain equilibrium. They cautioned against placement of dredged material along the updrift shoreline to reduce rehandling during navigation maintenance dredging and raised concern over excessive dredging (of volume) that may compromise the balance between the growing ebb-tidal delta and adjacent shoreline stability. Additionally, Welsh and Cleary (2007) suggest that Jarrett's (1976) equation relating tidal prism and cross-sectional area were useful in the inlet relocation analysis, but cautioned against using Walton and Adam's (1976) empirical formulation for equilibrium ebb-tidal delta volume. 
In China and the Netherlands, some research (Wang et al. 2012; Wang et al. 2014) has focused on redistribution of tidally and littorally derived sediments within the system to maintain navigation channel depth requirements as well as overall system volume retention and function. Hibma et al. (2008) modeled the effects of dredging and in-water placement of sand within a multi-channel, funnel-shaped embayment and conducted a channel stability analysis on the morphological results of ebb and flood-oriented channels. Their analysis focused on the effects of erosion and accretion in adjacent channels and shoals with respects to the placement location, and they found that placing sediment in a channel induces erosion in an adjacent opposite channel. They also verified the concept of ebb-flood channel cells, originally described by van Veen (1950), which are morphological units with partitioned flood and ebb dominant channels. Their analysis of the spatial footprint of dredging within these ebb-flood channel cells indicated that dredging the shallow partition area between ebb and flood cells may induce erosion in all nearby channels. Their recommendations with concerning dredging and placement is to limit in-channel placement to $<10 \%$ of the gross sediment transport flux of that channel.

A study on the effects of artificial breaching of an immature ebb-tidal delta in Guadiana Inlet, Portugal and Spain, identified the dominant sediment transport pathways of a recently jettied inlet (Garel et al. 2014). Although not focused on the usage of the mined material in their analysis, their focus on the long-term response of the ebb-tidal delta to the construction of an updrift jetty had concluded that the ebb-tidal delta morphodynamics were still evolving toward an equilibrium state that may require decades to achieve and that management strategies for the inlet and adjacent beaches should consider this multi-decadal timescale. The artificial breaching of the ebb-tidal delta for navigable purposes was discussed in terms of limited benefits to navigation and potential longer temporal impacts to the already reduced bypassing potential of the ebb-tidal delta, which contributes directly to the downdrift erosion of adjacent beaches.

Further, Garel et al. (2014) discussed the limited benefits of dredging the "collapsing ebb-tidal delta" as that reduced the capacity of the existing downdrift shoals to protect the shoreline from wave energy. Beck and Legault (2012) found a similar result in numerical simulations of increased mining footprint and overall sediment volume for adjacent shoreprotection projects. Garel et al. (2014) reasoned that the detriments to 
shoreline erosion outweighed the short-lived benefit of utilizing the readily available sediment and therefore suggested implementing engineered bypassing procedures with respects to a system-wide understanding of sediment dynamics of the area. In the case of Guadiana Inlet, they suggested that any dredged material should be placed at the location of the old inlet channel, centrally located in the longshore transport divergence zone downdrift of the inlet.

Finkl et al. (2007) reviewed the sediment resources of the West-Florida inner continental shelf and specifically highlighted the ebb-tidal deltas as historical and present sources for beach nourishment. This microtidal coast exhibits a wide range of tidal inlet characterizations from tide to mixed energy to wave-dominated, and their differing dominance in processes determines the size of their ebb-tidal deltas. Finkl et al. (2007) contended that the smaller more wave-dominated inlets are better at bypassing sediment than the larger tidally dominated inlets and that the larger inlet ebb-tidal deltas are essentially long-term or "permanent" sediment sinks. Larger, tidally dominated inlets were suggested as optimal potential sediment resources for the region as their size and mining site proximity to the shore would likely reduce impacts of sediment bypassing and wave sheltering on adjacent beaches.

In Finkl (2012), the various engineering and environmental concerns surrounding the practice of mining ebb-tidal deltas is reviewed in the context of potential pitfalls of poor shoreline management practice. Finkl reasoned that poorly designed engineering studies, or a lack thereof, may result in dredging activities at inlet deltas that can "upset the natural equilibrium to the point in extreme cases where the delta collapses," citing a study by Kelley and Bothers (2009). A sand-sharing system such as that of tidal inlets and adjacent beaches is in a delicate balance that is easily disrupted by the perturbation of removal of littoral sands from any part of the system.

The sand deficit within the United States has been reviewed by many researchers over the last several decades (Douglas et al. 2003), but the most critical numbers identified by Finkl (2012) are summarized here:

- Of the world's sand shorelines, approximately $75 \%$ are eroding, and within the U.S. that number has been estimated to be upwards of $90 \%$ by Leatherman (1988). 
- Approximately $1 \times 10^{9} \mathrm{~m}^{3}$ of sediment has been removed from U.S. beaches in the past century (Douglas et al. 2003).

- Approximately $650 \times 10^{6} \mathrm{~m}^{3}$ of sediment have been dredged from inlets, harbors, and continental shelf deposits and placed on sandy beaches (Finkl et al. 2006).

Aside from the general concerns for the quantities of sandy sediments lost to dredging and removal from littoral systems, structured inlets have trapped considerable quantities of sand in their fillets and substantially changed the morphodynamics of the ebb-tidal deltas and their bypassing processes (Dean 1993; Finkl 2012). Suggestions to mitigate the effects on the stability of the ebb-tidal deltas and their adjacent shorelines include optimizing the alignment of a maintained navigation channel in its natural orientation (Price 1951; Dabees and Kraus 2008), and engineered sediment bypassing alternatives such as a weir or bypassing plant (Bruun 1978; Bruun 1995; Finkl 2012). Seabergh and Kraus (2003) summarize management practices for natural and engineered tidal inlet bypassing with special focus on weir jetties, jetty spurs, and other engineering aids. They maintained that artificial bypassing, or engineered bypassing, could work to harmonize the human requirements to maintain navigation channels with natural, or historical, sediment-sharing requirements between inlets and beaches.

\subsection{Sediment reservoir models}

A substantial quantity of littoral sand is stored in tidal inlet deltas, also described as sediment sinks or reservoirs within barrier-inlet systems. In recognition of the need to understand the long-term behavior of these sediment reservoirs, the Inlet Reservoir Model (IRM) was developed by Kraus $(2000,2001)$ to relate and quantify the sharing of net sediment drift that enters a tidal inlet and is redistributed along various pathways between the morphological features. In its simplest form, the IRM suggests that sediment enters an inlet through the two primary modes defined by Bruun and Gerritsen (1958): flood-generated import of sediment into the inlet channel and alongshore wave-induced bypassing onto offshore inlet morphological features such as attachment and bypassing bars adjacent to the beach. Connections made between shoals following these two pathways may be construed a number of ways dependent upon specific inlet morphologies, hydrodynamics, structural controls, and anthropogenic effects to inlet processes such as dredging and placement. Regardless of how sediment is shared between the features, 
sediment can exit an inlet system near equilibrium via transport across the downdrift shoal systems and attachment bar. Figure 6 illustrates the IRM where the net littoral drift (QIN) fills the ebb-tidal delta, and as it approaches an equilibrium volume $\left(\mathrm{V}_{\mathrm{Ee}}\right)$, each subsequent reservoir in the general sediment bypassing pathway captures sediment from its "updrift" reservoir (from Kraus [2000]).

Figure 6. The IRM describing the net littoral drift ( $\left.\mathrm{Q}_{\mathrm{IN}}\right)$ into the ebb-tidal delta $\left(\mathrm{V}_{\mathrm{Ee}}\right)$ and how each subsequent reservoir in the general sediment bypassing pathway captures a reduced quantity of sediment from its updrift reservoir (modified from Kraus [2000]).

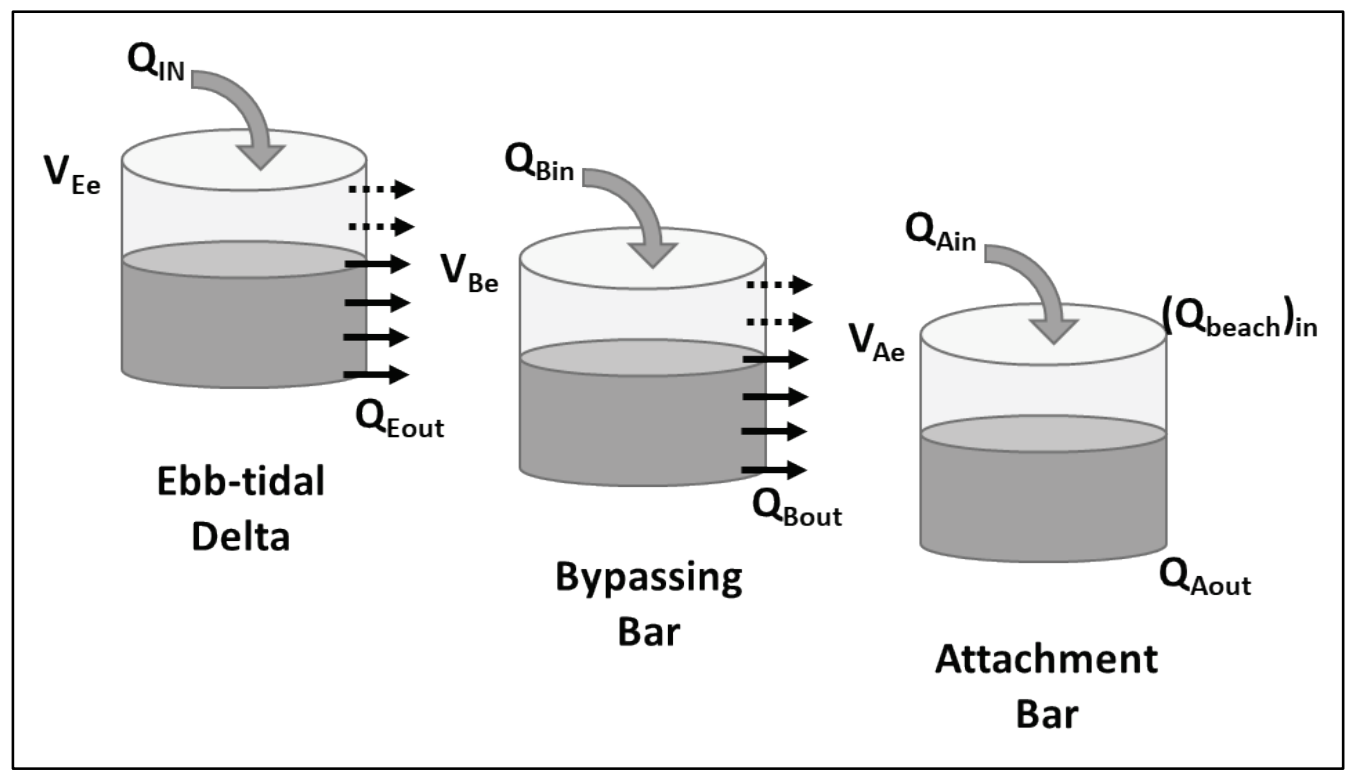

This study suggests that emphasis placed on wave-induced alongshore transport from adjacent updrift beaches on to the ebb-tidal delta platform via attachment bar and bypassing shoals (and the reverse along downdrift beaches in net sediment transport reversal periods) should be scrutinized and evaluated through measurement and modeling (Dabees and Kraus 2008). The processes and conditions by which sediment may enter an ebbtidal delta directly from the beach have not been studied in detail, warranting further research to understand where this process is important and what the relative contribution should be for inlet reservoir management studies. This echoes the conclusions of Mehta et al. (1996) to evaluate the role of alongshore sediment transport in sediment bypassing pathways in tidal inlets.

Garel et al. (2015) analyzed the ebb-shoal collapse of Guadiana Inlet and the recovery of volume and established bypassing bars. They cited Walton and Adams (1976) to estimate total equilibrium volume but found that the inlet 
had reached some quasi-equilibrium after 20 years of equilibration instead of the estimated 80 years required via the IRM (Kraus 2000, 2001). They cited the initial volume of the collapsing, relict ebb-tidal delta shoals as the primary source allowing the inlet to reach near equilibrium volumes. There was limited investigation about the estimated equilibrium volume.

Comparatively, research on the Wadden Sea tidal inlets in The Netherlands has focused on differing objectives due to the fact that they are all presently flood dominant and are actively importing littoral sediment (fines and sands) into the basin in a long-term response to the closure of the Zuiderzee in 1932. Studies by FitzGerald et al. (2008) and Oost et al. (2014) have discussed sea-level rise and tidal inlets as becoming increasingly flood dominant as sea level in the estuary/basin increases and the tidal signal becomes more asymmetric. Additionally, Wadden Sea tidal inlets are losing volume within their ebb-tidal deltas as a result the sediment import into the basins. The tidal inlets of the Wadden Sea can be studied as case examples on the impacts of sea-level rise on an estuary system.

The Aggregated Scale Morphological Interaction between a Tidal inlet and the Adjacent coast model (ASMITA) was built upon the IRM to connect to basins and adjacent coastal littoral sources such as barrier islands, shoals, and headlands (Stive et al. 1998; Stive and Wang 2003). Similar challenges in the setup of this model arise when assigning coefficients of exchange between the various morphological features, and the use of numerical modeling in combination with measurements for validation is suggested to refine the input parameterization. Dissanayake et al. (2011) compared the process-based model, Delft3D, to the semi-empirical aggregate model, ASMITA, and found similar predicted evolution of aggregate inlet features over decadal timescales.

In van Rijn's (2015) study on schematizing sediment transport at tidal inlets in the Wadden Sea, an aggregate model of inlet features for three large inlets was defined and presented. The aggregate model defined the interconnected pathways of sediment transport across the dominant geomorphic features of a tidal inlet and basin with the inclusion of hydrodynamic data over a multi-decadal timescale and was applied to study the long-term response of three inlets to sea-level rise scenarios. The schematization of each inlet was at the coarsest level, defining the bounds of the outer basin (ebb-tidal delta), inlet throat, and the inner basin (flood- 
tidal delta), and it refined each feature with assumptions about the volume of the geomorphic features with respect to elevation levels.

One substantial assumption in the van Rijn's (2015) study was that the import of sediment into each inlet would remain steady through time, regardless of mining activities or sea-level rise scenarios that would ultimately contribute to increased tidal prism and tidal asymmetry that would increase net sediment transport into the inlets (van Rijn 2015). The remaining assumptions made in the model impacted the interconnectivity between each feature based on an established understanding of the equilibrium cross-sectional channel process and capacity of the tidal prism to import a steady quantity of sediment. Additional sea-level rise in excess of $2 \mathrm{~mm} /$ year was found to have degradational effects on the basin sedimentation rates, but that rates similar to present were found to be largely similar to present depositional rates. This relatively stable relationship under present sea-level rise conditions is likely attributable to the stable sediment import assumption, and any changes in littoral volume contribution would impact the overall results of the modeled long-term responses. Van Rijn (2015) found that the inlet's net import of sediment was less sensitive to an increase in sea-level rise than to the parameterization of the ebb-tidal delta volume, elevation, and how much sediment would be eroded from adjacent beaches given specific dimensions of the ebb-tidal delta.

\subsection{Regional sediment management (RSM)}

The balance of regional and local sand resources at inlets and adjacent beaches over longer temporal scales (decades to centuries) is key to sediment management. There are increasing demands within the United States to mine tidal inlet deltas as well as their navigation channels for use in beach nourishment in addition to other competing social, environmental, and economic drivers. Evaluation of tidal inlet and sediment transport processes within the context of a regional framework is not a simple task and often requires the support of extensive field data collection, historical geomorphic data analyses, and numerical aggregate morphodynamic models or process-based hydrodynamic and morphodynamic models.

Finkl (2012) asserts that limited post-mining data exist to assess the impacts on the sand-sharing littoral system and that few studies have accurately quantified the rate of recovery possibly owing to the uncertainty 
in the equilibrium volume of inlet deltas, sand availability, storm frequency, and dimensions and depth of the mining pit. Potential for overuse of tidal inlet deltas is high when the regulatory requirements are centered on project-specific analyses that do not consider regional impacts at adequate temporal scales (Finkl 2012). Multiple mining episodes in rapid succession can drastically compound bypassing, erosion, and sedimentation issues between the inlet and adjacent beaches. Furthermore, engineering at multi-inlet systems may expand the spatial impact because modification at one inlet may trigger significant changes at another one, cascading potentially greater downdrift-associated problems over decades to centuries.

Roelvink (2015) reviewed the state of the world's sediment resources for use in littoral nourishment efforts. He found that sediments, and particularly sandy, littoral sediments, are becoming increasingly rare minerals and that coastal managers will look to utilize more readily available sediments contained within tidal inlet delta reservoirs. Here, Roelvink strongly cautions against the extraction within any sediment sharing systems as that will lead to erosion elsewhere. Management of these resources will require an increased economic value of these resources beyond the costs of extraction to make responsible planning decisions regarding these dwindling resources.

Bruun (1995) described the impact to shorelines downdrift of natural and artificial littoral drift barriers as having short and long erosional waves with long waves (greater than $1 \mathrm{~km}$ ) moving 2-3 times faster than short erosional waves (less than $1 \mathrm{~km}$ ). Tidal inlets have been widely reviewed for their downdrift impacts, and Bruun contends that their sediment bypassing characterization is the best indication for determining the extent and magnitude of downdrift erosion. He also points out that further deepening of the inlet channel through the ebb tidal delta bar can substantially alter the bypassing mechanism, which was verified by Ridderinkhof et al. (2016), thereby impacting the erosional response along adjacent beaches.

Bruun (1995) describes the effects of short waves as geomorphological features whereas long waves induce a materials deficit that is not as distinct, potentially contributing to misunderstanding or ignorance in evaluation for regional management. Similar to Roelvink (2015), Bruun maintains that the erosional problems caused by inlets and entrance 
channels must be mitigated against and serve as reason to adopt laws preventing the creation of new littoral barriers. He cites the role of public agencies in their regulation and maintenance of littoral barriers and that new law must be generated to establish "firm 'coastal ethics."”

French et al. (2016) discuss the need for conceptual frameworks within which scientific advances are made in methods, field discovery, and modeling of coastal change. The researchers discuss a trend in shifting away from reductionist models towards more explicitly resolved models that capture mesoscale coastal morphodynamics (decades to centuries). Their study, as well as that by Nicholls et al. (2012), argues that conceptual frameworks by which these modeling systems are employed have not evolved with the improved understanding of coastal and estuarine management and the challenges at present. In analyzing morphodynamic behavior, often the focus is on the relative volume change, and substantial assumptions are made on the interconnectivity between the morphological features in the sediment sharing system. French et al. (2016) argue that when conducting regional sediment budgets, the need to balance the budget leads to assumptions about the connectivity between morphological features that have yet to be determined, or are later found not to be directly connected.

As a means of providing an interface between science, policy, and management, the Coastal and Estuarine System Mapping (CESM) system is a geomorphological framework that resolves littoral cell-based segments of the coastal and estuarine zones for management planning (French et al. 2016). Additionally, French et al. (2016) recognize the importance of stakeholder buy-in and understanding from the perspective of the citizen impacted by management decisions and that the CESM can help engage the public stakeholders in such a way.

Wang et al. (2007) developed a sediment budget for the coastal zone along the Western Scheldt and Wadden Sea of the Netherlands to address management questions about long-term sand import/export and interactions between estuaries and coastal processes. In this study, they attempted to determine why there was a discrepancy between the measured sand export of the Western Scheldt and decreasing ebb-tidal delta volumes. The influence of relative sea-level rise and tidal asymmetry were also taken into account as well as anthropogenic modifications (dredging, mining, and placement). 
Ultimately, the Western Scheldt is deepening and exporting approximately 1 million $\mathrm{m}^{3}$ of sand per year while the coastline is losing approximately 10 million $\mathrm{m}^{3}$ of sand per year. The Wadden Sea is importing more sediment than it needs to keep up with relative sea-level rise, with approximately half of the import accounting for impacts due to the closure of the Zuiderzee. Altogether, the Wadden Sea imports approximately 12 million $\mathrm{m}^{3}$ of sand per year through multiple tidal inlets. This is approximately the same volume of sediment that is used to nourish the Dutch coast, which is not sufficient to counteract both coastal erosion and sediment importation into the Wadden Sea.

Long-term geomorphological considerations include the loss of intertidal flat areas along the Western Scheldt, and a decreasing bypassing capability of the decreasing ebb-tidal deltas along the barrier island chain of the Wadden Sea. Wang et al. (2007) suggest that the implications of coastal sand management policy will have a significant effect on the rates of erosion and sand import into tidal basins and therefore should be carefully studied and consider the following: ecological functioning, sand mining, maintenance, recognizing interconnected systems and not political boundaries, and alternative nourishment methods including ebb-tidal delta nourishment and large-scale beach nourishments such as the "Sand-Motor."

Wang et al. (2012) broadly reviewed morphodynamic studies along the Wadden Sea and suggested knowledge gaps both for the region and generally for barrier-inlet systems. Some of the knowledge gaps include the following:

- There are not sufficient measured datasets concerning the sediment transport field, broadly across tidal inlets.

- There is a need to understand morphodynamics and building sediment budgets with respect to various grain size distributions and particularly between the mud and sand fractions within the estuaries that tidal inlets serve. Additionally, the relative distribution of available grain size in various morphologic formations in barrier-inlet systems is not well understood, and this has implications on sediment transport and management of sediments.

- There exists various levels of uncertainty in volumetric sediment budget studies, and little data illustrate the amount of variation and error in these computations. 
- Understanding submerged feature morphodynamics such as the shape and cross-section of channels in basins, cyclic behavior of ebb-tidal deltas, and the size, shape and bed level of inter-tidal flats needs to be improved.

In Wang et al. (2015), the effects of human impacts on the morphodynamics of two estuarine systems were examined to review the critical threshold by which natural morphodynamics would be permanently altered. They analyzed the Scheldt Estuary and the Wadden Sea basins in the Netherlands and the Yangtze Estuary in China and reviewed human activities including engineering and dredging activities for navigation, flood protection, and shoreline management. Their use of defining "exceeding thresholds beyond which the morphology of the tidal basins significantly changes, and loses its natural characteristics," also known as a "tipping point," is an important aspect to consider in long-term management planning of a coastal system. Wang et al. (2015) define thresholds at differing spatial scales for specific activities such as a "limit to rate of disposal" for a channel at the "Macro-scale," and discuss the knowledge level around the threshold, whether or not there is a definite tipping point, and the consequences if the threshold is exceeded. Specific examples look at basin-level sediment budgets, project level planform area or volumetric change, or specifically cross-sectional area or depth change within a specific channel. Although they found that the values and levels of thresholds were quite specific to the areas they studied, the approach and types of thresholds are applicable to other tidal basins.

The concept of RSM, or a systems management of sediment resources, originated out of a shared and growing understanding of long-term and regional impacts of sediment management practices (Rosati et al. 2001). RSM is a management practice within the U.S. Army Corps of Engineers (USACE) that coordinates multiple sediment-related engineering projects within a region across multiple business lines in a systems-based approach to achieve greater benefits to the navigation, flood and coastal systems risk management, and ecosystem restoration missions through optimization of the use of sediment resources (Childs 2015; Rosati et al. 2001; Lillycrop 2011; Kress et al. 2016; Schrader et al. 2016).

Management of an inlet's hydrodynamics and morphodynamics are in large part connected to the management practice of adjacent barrier island beaches, and at the regional scale, is considered RSM. Over longer 
timescales, such as centuries, the impacts of sea-level rise, climate change (e.g., storm intensity and frequency), long-term cross-shore and longshore sediment transport patterns, regional-scale uplift or subsidence, and regional-scale sediment supplies affect tidal inlet dynamics. Therefore, coastal managers should also evaluate long-term changes at one or multiple inlets considering the connected, sand-sharing, and basin-wide barrier-inlet system. 


\section{Barrier-Inlet System Sustainability and Long-Term Management Perspectives}

Chapters 2 and 3 focused on a review of investigations into tidal inlet morphodynamics and sediment management of coastal barrier-inlet systems. The natural evolution of these geomorphic features over geologic timescales, particularly centuries to millennia, has been investigated over the last two centuries (Schwartz 1971) with continued refinement of existent hypotheses in the scientific literature. Understanding the natural evolution informs engineers and scientists on how processes have behaved in the past and what they are expected to do under future conditions, which provides a baseline for understanding the effects of anthropogenic modifications to, and the potential sustainability of, barrier-inlet systems.

\subsection{Natural barrier-inlet development and evolution}

In the geologic discipline, there are several theories that describe the development of barrier islands (and subsequently their tidal inlets). De Beaumont (1845) described barrier construction as "wave action on a shallow bottom removes sediment and piles it up to form a bank or barrier that parallels the original shoreline, thus establishing a balanced profile above and below mean sea level" (Schwartz 1973). Others have indicated that the barrier islands formed through the cutting of sandy spits or through the submergence of coastal ridge features (Schwartz 1973). Schwartz (1971) summarizes these as all plausible hypotheses that may make up the spectrum of processes forming barrier islands under rising and falling sea level sequences.

Research has linked the development of the Holocene barrier islands to the slowed rate of sea-level rise over the last 3,000-5,000 years (Davis 1994; Davis and FitzGerald 2004). A fall in sea level results in a regressive stratigraphic sequence of ocean-ward deposition by rivers and coastal littoral sediments, and a rise in sea level may result in a transgressive sequence of landward migration of sediments including barrier islands. Many Holocene islands studied have been linked with a steady aggradational process due to the slowed rate of sea-level rise.

In the stratigraphic record, wave-dominated (sandy) coastal plains are common; however, the distinct bedforms and geomorphic features of barrier islands sediment lenses are not as well preserved as tidal inlets 
(Hoyt and Henry 1967). This may be attributed to the theory of selfcannibalizing barriers under sea-level rise, which consists of barrier island "rolling over" and onshore transport of the sedimentary features that did not keep up with sea-level rise. The preservation of barrier islands under transgressive sequences has been linked to the substrate below the active barrier island (typically the sand-sized sediments) (Hoyt and Henry 1967).

Moore et al. (2010) found that the depth of larger-sized sediments, sands and gravels associated with tidal and riverine inlet incisions, was correlated to the longevity of the barrier and its ability to "roll over" and preserve that coastal barrier feature. If the materials of the substrate are greatly different, however, the erosion of the coastal barrier through roll over and alongshore gradients may result in degradation in the long-term. This may indicate that the preservation potential of natural barrier-inlet systems will depend upon their underlying geological substrate under global sea-level rise.

Investigations into the sustainability of barrier-inlet systems require an indepth understanding of the processes that generate these geomorphic features and the forces that maintain their development or eventual degradation. Tidal and wave forcing are key factors in the constructive and destructive forces that maintain deposition of sediments in the nearshore environment (Dean and Dalrymple 2002). These processes rework sediment within a lens, or layer, of sediment deposition across the continental shelf at shorter timescales (hours to days) than the relative change in sea level, and they are important mechanisms facilitating the migration or translation of littoral sediments up and down the shelf with the rise and fall of sea level at millennial timescales. The variability of tidal and wave forcing may play a crucial role in the long-term preservation potential for different barrier-inlet systems.

\subsection{The effects of sea-level rise on inlet processes and long-term evolution of natural barrier-inlet systems}

Tidal inlets are ephemeral in their occurrence along barrier coasts, typically lasting approximately 10 s to 100 s of years, though they may persist longer if anchored through geologic constraints. The primary processes that occur in a natural barrier-inlet system as sea level rises include the following: the landward migration or rollover of the barrier island through overwash and landward aeolian transport of sand; barrierisland breaching, establishment, alongshore migration, and closure of 
inlets; ebb-tidal delta shoal avulsion and onshore migration of offshore sediments from the continental shelf. Tidal inlets play a significant role in shoreline erosion and accretion along barrier islands, as well as landward deposition through flood-tidal delta development. A plan view and crosssectional diagram of the barrier-inlet depositional sequence, originally by Pettijohn et al. (1988) and modified by FitzGerald et al. (2008), illustrate characteristic depositional features including washover fans and laterally migrating channel fill sequences Figure 7.

Figure 7. Plan view and cross-sectional diagram of tidal inlet stratigraphy illustrating the sedimentology of a stable and migratory tidal inlet in a barrier-inlet system (from FitzGerald et al. [2008], originally developed by Pettijohn 1988).
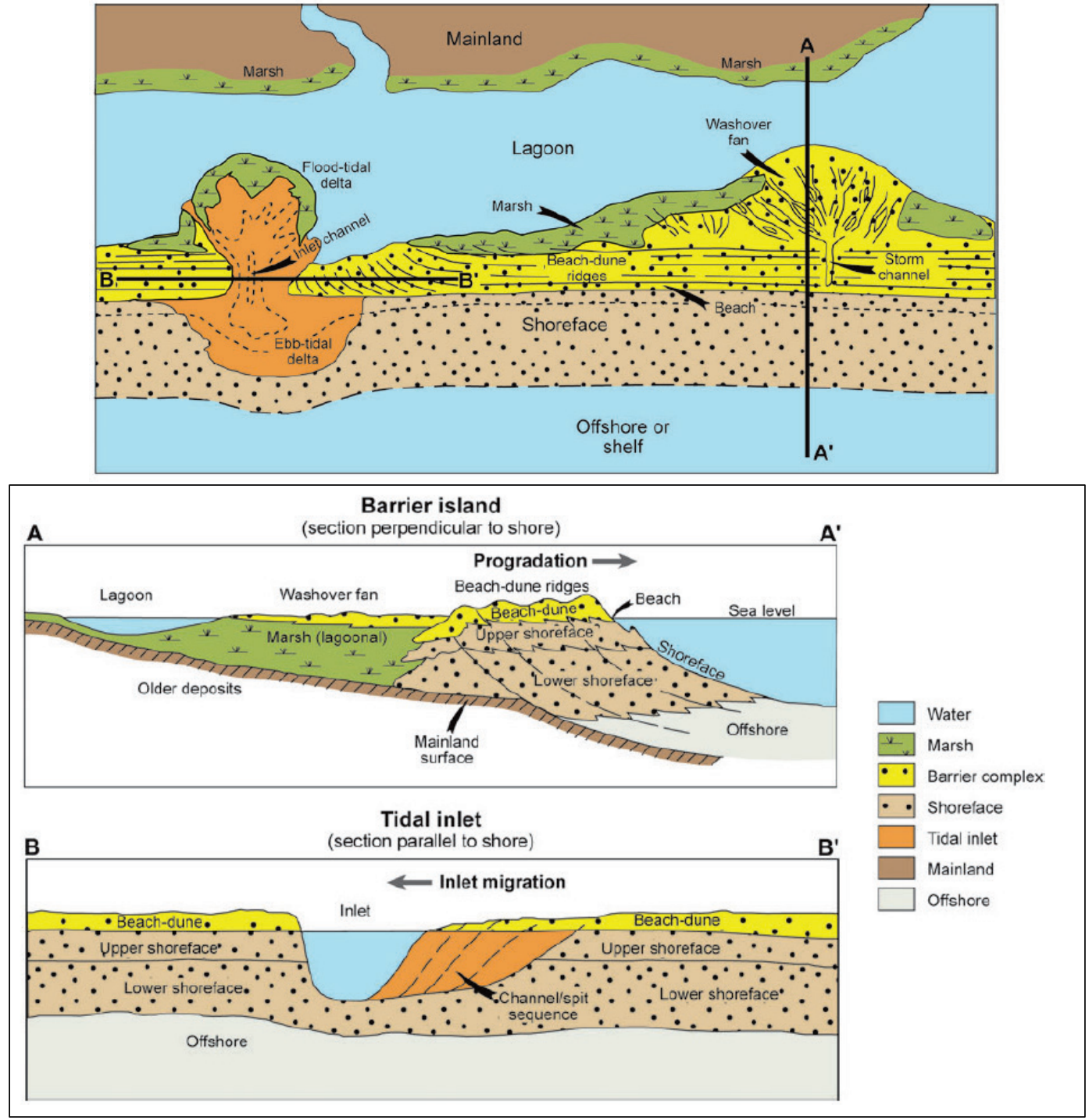
The role of tidal inlets in barrier-inlet transgression over the temporal scales of their existence (10s to 100 of years) is highly dynamical due to their relationship to the tidal prism of a basin and the wave-driven littoral sediment supply from the coast. In general, the equilibrium relationships of tidal prism to inlet cross-sectional area as well as ebb-tidal delta volume have been validated for cases where relative sea-level rise had increased basin area and tidal prism, thereby increasing the cross-sectional area of the tidal inlets and sequestration of barrier sediments into tidal inlet deltas (FitzGerald et al. 2006). FitzGerald et al. (2008) summarized the cumulative effects of barrier-inlet processes in the context of sea-level rise:

- The initiation of barrier island rollover will occur within 50 to more than 100 years dependent upon rate of sea-level rise, erosion rates, frequency of storms, and the volume of sand contained within the barrier.

- Barriers will tend to segment with more breaches through lowered barrier topography (due to the reduction in sand supply), increasing the number of tidal inlets and capturing more littoral sand from the open coast.

- Inlet breaches along open water stretches of basins will sequester more sediment than inlet breaches through healthy wetland/marsh backbarrier environments, thereby reducing the areal extent of subaerial sedimentation resulting in limited changes to tidal prism.

- Changes in basinal hypsometry will affect tidal asymmetry and prism, complicating the infilling patterns of the basin and further modifying the tidal asymmetry and overall prism.

- Smaller inlets with a smaller tidal prism may be better able to respond to sea-level rise as their cross-sectional areas widen, tidal prism increases, and yet their import of sediment into ebb- and flood-tidal deltas does not exceed the littoral-derived (or riverine-derived) supply.

- Larger inlets with a greater tidal prism, however, may require a greater import of sediment than available from the sediment supply, causing their deltas to decrease relatively in size and effectively drown the inlets.

- Drowning of tidal inlets under sea-level rise, or the reduction in functional tidal prism-equilibrium sedimentation rates, can be exacerbated by accelerations in substrate subsidence and wetland conversion to deeper, open water. 
The role of sediment supply in barrier-inlet system response to sea-level rise has been evaluated in both aggregate modeling as well as numerical analyses. Sediment budgets have been shown to demonstrate the overall sediment sources and sinks of barrier islands systems including projected beach erosion and accretion (Rosati 2005). If one assumes that the littoral sand supply along barrier islands do not vary, and embayment orientations do not change substantially given island migration, roll over processes and the resultant sediment budget may conform to a predictable model. However, this may not be practical in most natural systems, where barrier dissection or changes in island orientation may change the net littoral drift and therefore affect the sediment supply in a barrier island chain.

The rollover potential has also been found to be related to the geomorphic shape and orientation of the basin and the sediment contained within the barrier and estuarine. In a study by Moore et al. (2010), the North Carolina outer banks barrier islands were predicted to have the capacity to continue to roll over and migrate landward due to the supply of sandy materials in the substrate of the embayment and due to the sufficient wave energy to mobilize sediments onshore at the rate necessary to sustain barrier widths. However, the low-wave energy Louisiana barrier islands are in a delicate balance of conditions and have been found to have limited sand supply in their substrate in addition to the relative sea-level rise occurring there (Rosati 2009). Their migration potential may be more related to changes in the basin shape, orientation, and supply of sediment in the substrate rather than the capacity of the overall wave energy to transport sandy sediments landward.

Duong et al. $(2015,2017)$ reviewed the impact of specific climate change variables, specifically sea-level rise and wave climate, on the morphodynamics and stability of small tidal inlets. One significant finding of their studies was the relative importance of a change in longshore sediment transport rates on the overall dynamics of the tidal inlet. Of the three types of inlets evaluated (stable, unstable and migratory, and intermittently closing), climate change driven variations (such as sea-level rise or storm direction, frequency, and intensity) can increase or decrease the speed at which small migratory inlets move and/or close. Increasing sea levels would tend to slow this migratory process, yet increasing storminess and changes to wave direction and/or intensity may speed up the process. Additionally, they found that potential changes in tidal prism would play a larger role in inlet stability. 
In van der Wegen (2013), a process-based numerical modeling approach to long-term modeling (10os of years) predicted known responses in tidal asymmetry and sediment importing in variable tidal forcing and basin settings under accelerating sea-level rise. However, there were variable results on the tidal inlet cross-sectional response to tidal prism, leading to the conclusion that the prism to area relationship exists for the first several decades but then diverges over time with cross-sectional area continuing to increase even with a constant tidal prism. In all but a few scenarios, the basins eventually cannot import sediment fast enough to keep pace with present sea-level rise rates of $\sim 0.5 \mathrm{~m} /$ century and effectively "drown," with the rate of acceleration of sea-level rise controlling the rate of decay of intertidal area. A unique situation identified in the modeling effort was the effect on very shallow embayments with low tidal forcing, which demonstrated continued sediment export under initial sea-level rise scenarios attributed to substantial tidal wave dampening. Overall, the focus of this study was limited to the sand exchange between the littoral coast and basins through tidal inlets; it did not consider barrier island processes under the effects of sea-level rise and the implications for regional scale coastal processes.

Rosati (2009) and Rosati and Kraus (2009) developed a decadal-scale, multi-barrier island, sediment budget model based on empirical relationships of tidal prism to inlet cross-sectional area and tidal delta volume to investigate aggregate changes under sea-level rise and basin area change. Under the assumption of conservation of volume, the barrier islands were also assumed to behave as reservoirs in a sediment budget but with fixed alongshore sediment transport rates (assuming no changes in orientation or wave energy). In a validation study at Barataria Bay, Louisiana, they found that the historical changes in inlet cross-sectional areas and tidal delta volumes were larger than the equilibrium values supporting the relationship, which skewed the overall results. They attributed this offset in values to the fact that the barrier-inlet systems were already degradational with increasing tidal prisms and inlet crosssectional widths and areas.

\subsection{Anthropogenic effects: A focus on barrier-inlet systems of the United States}

Humans have changed coastal barrier islands and tidal inlets broadly across the United States through impacts on sediment supply from the damming of rivers to direct changes to the coastline through engineering 
works. From a U.S. perspective, the most significant activities or changes to barrier-inlet systems include the creation of new inlets (Dean 1988; Dean and Work 1993), closure of breaches, shoreline stabilization, navigation channel stabilization (including structures), dredging channels to change orientation, depth and width, sand mining and placement (Roelvink 2015), littoral and riverine barriers to supply basins, and mineral and groundwater extraction effects on substrate consolidation (Bruun and Gerritsen 2005).

Dean (1988) reviewed the earliest developed U.S. policies and practice related to the management of altered and/or constructed tidal inlets in Florida and concluded that all government policies regarding coastal sediment and tidal inlet implications should strive to reinstate the continuity of "natural net transport of sand" around inlets. The study reviewed important inlet-beach interaction factors including net and gross longshore sediment transport, structure design, and sediment dredging and placement practices. Dean (1988) proposes that beach sediment losses are attributable to the following:

1. "blocking of net longshore sediment transport by the updrift jetty,

2. flow of sand over and through low and permeable jetties,

3. jetting of sand farther seaward to the ebb tidal shoals, and

4. removal of sand to maintain channel depth with disposal in deep water."

\subsection{Long-term management of barrier-inlet systems}

\subsubsection{Advancements in regional budgets of barrier-inlet systems in the United States}

Bruun (1978) formulated a simple, cross-shore model (known as the "Bruun Rule") that describes the landward migration of a barrier beach coupled with offshore sedimentation in the shelf to conserve sediment volume across a beach profile under the rise of sea level. Dean (1987) furthered the model to describe the effects of alongshore transport of sediment along a beach profile at equilibrium (Equilibrium Beach Profile model). Rosati et al. (2013) discussed the inclusion of landward sedimentation processes on the Bruun Rule, which improves the realistic nature of barrier island transgression. 
Recent studies in the United States on the impact of sea-level rise to barrier island long-term sustainability by Houston and Dean (Dean and Houston 2016; Houston and Dean 2016; Houston 2017) estimated large regional sediment budgets for the east, southwest, and west coasts of Florida using beach profile data, inlet shoal volume data, historical and projected sea-level rise, and a list of engineering works (e.g., dredging, beach volumes). Their approach to compute sediment budgets of entire coastlines and deduce the effects of sea-level rise on shoreline recession include several critical interrelated factors influencing sediment dynamics along barrier islands. Sea-level rise induced volumetric-change computations of the barrier islands are based on the Bruun Rule and rely heavily on the depth of closure determining profile width and therefore controlling the estimations of erosion rates on total island area. When adding together the volume change from passes, sea-level rise, longshore transport, and engineering works (e.g., beach nourishment), they found that total predicted shoreline changes should indicate a recession rather than an advance.

However, Dean and Houston (2016) found that the inclusion of an onshore flux of sediment supplying the beaches balances the sediment budget. Basing onshore transport on shallow-water wave theory with generally onshore-directed bottom shear stress on the continental shelf, as well as documentation from other studies, they theorized that onshore transport across the continental shelf is indeed realistic, and the concave shape of the beach profile further validates this hypothesis (Dean and Houston 2016; Schwartz 1973). Estimates were derived from past historical budgeting and are approximately $0.5 \mathrm{~m}^{3}$ per linear meter per year. These studies support the theory of a slow supply of sediment from offshore, or continental shelf, sources into barrier-inlet systems.

The most interesting aspect of Dean's and Houston's (2016) work is their notion of shoreline advance under a rising sea. They illustrated that under the present conditions, with availability of sediment, barrier islands may indeed not be rolling back but are actually aggrading, or prograding, seaward. Despite the hypothesized accretional forces, measured progradation in barrier islands is location specific. This finding may complicate present models of tidal inlet evolution dependent upon landward migration of barrier islands under a transgressive sea. The implications of onshore sediment migration and overall progradational barrier islands may affect the computation of local and regional sediment 
budgets, warranting the need for future regional sediment studies along a variety of coastlines and continental shelves.

\subsubsection{Future management for sustainable barrier-inlet systems}

Arguably, one of the most challenging research areas in the field of barrier island and tidal inlet management has been on the direct consideration of coupling these features and an understanding of their physical connectivity as a unified sediment sharing system. Although often managed separately on a project-by-project basis, these systems are more increasingly being viewed in the context of regional applications that attempt to holistically approach management decisions and engineering impacts.

A study by Wang et al. (2007) on sustainable barrier-inlet management conducted a comprehensive numerical analysis of the Dutch Wadden Sea tidal inlets to address research questions concerning the import of sediment into the Wadden Sea basin and the discrepancy between the measured sand export and a decreasing ebb-tidal delta for the Western Scheldt. Research questions included the following:

- How do the developments of the tidal inlets on the long-term look?

- What are the possible effects for the sand-balance of the Dutch coast?

- Which processes govern the developments?

- What are the influences of the development on the coast erosion of the island-heads and on the sand nourishment requirement for the coast maintenance?

Process-based Delft3D and the behavior-oriented model ASMITA were applied by Wang et al. (2007) to address the research questions using a comprehensive dataset that describes the geomorphic features and basic sediment transport processes. They determined that half of the sediment imported into the Dutch Wadden Sea basin is due to relative sea-level rise, and the remaining half is due to the impact of the closure of the Zuiderzee. There is a sea-level rise rate that would be greater than the capacity of the inlets to import littoral supply to keep the basin in morphological equilibrium with the tidal conditions. They estimate that it would take approximately 1 billion $\mathrm{m}^{3}$ to create morphological equilibrium of the basin accommodating for the effects of the Zuiderzee closure. Their computations for sand import into the Wadden Sea basins put the total volume of import at the same level as present day coastal nourishment volumes along that coast, indicating the need for a balanced approach to 
regional sand management between inlets, beaches, and tidal basins. Additionally, they also concluded that the decreasing size of the ebb-tidal deltas would exacerbate erosion along the barrier island headlands, accelerating coastal erosion already underway as the basins import approximately 10 million $\mathrm{m}^{3}$ per year.

Coastal management strategy recommendations laid out in the Wang et al. (2007) study include, but are not limited to the following:

- Integrate sand mining and coastal maintenance in decision making.

- Disregard local and national boundaries with regards to watersheds.

- Consider alternative nourishment methods, including the Sand-Motor and a large-scale nourishment of an ebb-tidal delta as a means to nourish sediment into sand-starved basins.

Oost et al. (2012) discuss the morphodynamics of the East and West Frisian Islands and a management perspective centered on a sedimentsharing barrier-inlet ecosystem. Of the many suggestions to enhance and support sustainability, sand nourishment is a key management option that "restore(s) the functioning of the larger eco-morphological units" in barrier-inlet systems. The Netherlands, Denmark, and Germany have worked collaboratively over recent decades on an integrated approach to planning and engineering efforts for the Wadden Sea.

More recently, a report by Oost et al. (2014) documents a research framework for sustainable management and preparation for climate change. The "learning-by-doing" adaptive management strategy includes monitoring and data analysis, system research and modeling, and field experiments or pilot projects. Most interestingly, as the Dutch Wadden Sea inlets are known to be flood dominant and losing sediment from the adjacent coastline and ebb-tidal deltas, one pilot project will introduce a large-scale (mega) nourishment to an ebb-tidal delta to increase the wave sheltering area behind the shallow shoal and potentially increase the sediment supply to the basin. This approach to sand management is focused at a larger geomorphic spatial scale with an expectation that the long-term effects of this project will take decades to study and understand.

More contemporary advancements in considering regional scales in longterm management of sustainable barrier-inlet systems in the United States have changed perceptions about coastal barrier-inlet systems (Childs 2015; 
Rosati et al. 2001; Lillycrop 2011; Kress et al. 2016). Examples of RSM practice for continental scale systems can be found in a number of resource managing agency approaches in the U.S. (e.g., Hodgens et al. [2016)] and Schrader et al. [2016]). For example, mineral management of offshore continental shelves has conducted regional scale evaluation of resources and comparing that to resource needs of that region such as that done for the Atlantic Sand Assessment Project (BOEM 2017).

Following National Environmental Policy Act guidance, research and engineering design has looked toward more cost-effective and ecologically considerate approaches for individual or project-level activities, such as the USACE Beneficial Use of Dredged Material or Engineering With Nature (Bridges 2011). Most recently, ecologically considerate engineering features have been evaluated and characterized as having natural or nature-based traits, or Natural and Nature-Based Features (NNBF) (Bridges et al. 2015). A relevant example of this method is the dredging of tidal inlet shoals and strategic placement along adjacent barrier islands to maintain the littoral sediment resources in the sand-sharing barrier-inlet system. Strategic placement of sediment on interior barrier shorelines (along the estuarine shoreline) can provide a platform for the migration of barrier islands that mimics the natural processes of overwash along managed coasts with designed barrier dunes and beaches. As the long-term impacts of those activities are evaluated across regions, more regional benefits may be ascertained. 


\section{Summary and Future Research Directions}

\subsection{Summary}

Coastal tidal inlet morphodynamics and sediment management practices for barrier-inlet systems were summarized. Tidal inlets are highly dynamical geomorphic features along barrier island coastlines, mobilizing and intercepting a substantial quantity of the littoral sediment contained within the sand-sharing system. Details of inlet morphology, sediment transport, and tidal inlet bypassing mechanisms provide the management practitioner an understanding of inlet behavior on short-to-medium timescales (months to decades). An understanding of tidal inlet morphodynamics can inform the coastal inlet manager or planner on best practices for engineering barrier-inlet systems over the long-term.

RSM is a management practice within the USACE that coordinates multiple sediment-related engineering projects within a region to meet multiple objectives through optimization of the use of sediment resources. A more regional perspective becomes integral to the computation of the long-term geomorphic evolution of tidal inlets and subsequent management approaches. At the single inlet scale, concerns over the general behavior of the inlet must also be evaluated in the context of longterm processes, which affect regional-scale systems.

The natural evolution of the geomorphic features of barrier-inlet systems over geologic timescales informs engineers, scientists, and coastal managers on how processes have behaved in the past and what they are expected to do under future conditions. Over longer timescales, such as centuries, the impacts of eustatic sea-level rise, climate change (e.g., storm intensity and frequency), long-term cross-shore and longshore sediment transport patterns, geologic isostacy and subsidence, and other important processes affect tidal inlet dynamics. Long-term studies conducted at regional spatial scales, including adjacent barriers and multiple inlets, are necessary to evaluate the cumulative effects of the aforementioned processes along with the effects of anthropogenic modifications, such as ebb-tidal delta mining and beach placement, to barrier-inlet systems.

\subsection{Future research needs}

- Investigate morphological considerations in sediment management practices at tidal inlets by evaluating the sediment pathways of the interconnected inlet features in addition to traditional hydraulic 
stability. This may be conducted through numerical studies or timeseries evaluation of morphodynamics. A more comprehensive dataset of various sediment bypassing pathways is required for characterizing the variety of sediment pathway models for wave- to tide-dominated inlets. Additionally, studies are needed to quantify magnitude and transport patterns at jettied inlets.

- Evaluate multi-scaled, RSM-related sediment budgets over years to multi-decadal timescales to capture short-term and longer-term processes and anthropogenic effects in the modern timeframe. Sediment budgets can vary substantially when considering morphodynamics of tidal inlets or long-term adjustment to sediment management by humans such as dredge and fill activities within a basin. Providing a range of regional budgets can allow decision managers to manage risk and individual project expectations.

- Characterize the tidal inlet basins of the United States for littoral connectivity and sediment balance between inland and coastal sediment resources to provide context for long-term sediment management strategies. Ebb- and flood-dominance, local and regional geomorphology, relative sea level change within the basin, and sediment sourcing all play a role in predicting the sediment balance of a tidal inlet and it's basin over decadal to century timescales.

- Evaluate Engineering With Nature and NNBF concepts for barrierinlet sediment management strategies that use natural processes to achieve an engineered outcome. Strategies may include sediment removal or placement to recover a natural balance disrupted by anthropogenic activities, or inclusion of ecomorphodynamic features (e.g., vegetated dunes adjacent to a jetty) for engineered structures designed for a flood protection or navigation-related purpose.

- Investigate the role of long-term sediment management plans through numerical simulations of barrier-inlet processes in the context of long-term processes such as sea level change. Sediment management at local tidal inlet projects influence overall basin sediment transport and dynamics and may play a significant role in a barrier-inlet systems capacity to naturally keep up with the effects of sea-level rise. Further research is needed to understand how these engineering activities will impact the sustainability of existing barrierinlet systems in the next century. 


\section{References}

Aubrey, D. G., and C. T. Friedrichs. 1988. "Seasonal Climatology of Tidal Non-Linearities in a Shallow Estuary." In D. G. Aubrey, and L. Weishar, Hydrodynamics and Sediment Dynamics of Tidal Inlets. New York: Springer-Verlag.

Aubrey, D. G., and P. E. Speer. 1985. "A Study of Non-Linear Tidal Propagation in Shallow Inlet/Estuarine Systems. Part I: Observations.” Estuarine and Coastal Shelf Science 185-205.

Beck, T. M., and K. R. Legault. 2012. "Dredging Optimization of an Inlet System for Adjacent Shore Protection Projects Using CMS and GenCade." Proceedings of the International Conference on Coastal Engineering, 1-14. New York: ASCE.

Bertin, X., G. Dodet, A. Fortunato, and N. Bruneau. 2013. "A Review of the Processes Controlling the Dynamics of Wave Dominated Inlets." Proceedings of Coastal Dynamics 2013, 24-28. Arcachon, France.

Bridges, T. S. 2011. Engineering With Nature (Fact Sheet). https://ewn.el.erdc.dren.mil/pdfs/EWNFactSheet_Final.pdf\#view=fit

Bridges, T. S., P. W. Wagner, K. A. Burks-Copes, M. E. Bates, Z. A. Collier, C. J. Fischenich, J. Gailani, L. D. Leuck, C. D. Piercy, J. R. Rosati, E. J. Russo, D. J. Shafer, B. C. Suedel, E. A. Vuxton, and T. Wamsley. 2015. Use of Natural and Nature-Based Features (NNBF) for Coastal Resilience. ERDC-SR-15-1. Vicksburg, MS: U.S. Army Engineer Research and Development Center.

Bruun, P. 1978. Stability of Tidal Inlets. Amsterdam: Elsevier.

Bruun, P. 1987. Discussion: "Sediment By-Passing across Coastal Inlets by Natural Means, by R. Silvester." Coastal Engineering 11(2): 175-181.

Bruun, P. 1995. “The Development of Downdrift Erosion.” Journal of Coastal Research 11(4): 1242-1257.

Bruun, P., and F. Gerritsen. 1958. "By-passing of Sand by Natural Action at Coastal Inlets and Passes." Proceedings of the American Society of Civil Engineers, 75-107. New York: ASCE.

Bruun, P., and F. Gerritsen. 1959. "Natural Bypassing of Sand at Coastal Inlets." Journal of Waterways and Harbors Division 85(4): 75-107.

Bruun, P., and F. Gerritsen. 2005. "Tidal Inlets on Littoral Drift Shores.” Journal of Coastal Research, Special Issue No. 46. Port and Coastal Engineering:

Developments in Science and Technology, 305-451.

Carr, E. E., and N. C. Kraus. 2001. Morphologic Asymmetries at Entrances to Tidal Inlets. ERDC/CHL CHETN-IV-33. Vicksburg, MS: U.S. Army Engineer Research and Development Center. 
Carr-Betts, E., T. M. Beck, and N. C. Kraus. 2012. "Tidal Inlet Morphology Classification and Empirical Determination of Seaward and Down-Drift Extents of Tidal Inlets." Journal of Coastal Research 28(3): 547 - 556.

Cayocca, F. 2001. "Long-Term Morphological Modeling of a Tidal Inlet: the Arcachon Basin, France." Coastal Engineering 42(2): 115-142.

Childs, J. L. 2015. Dredged Material Management Categories for Tracking Beneficial Use. ERDC TN-DOER-R22. Vicksburg, MS: U.S. Army Engineer Research and Development Center.

Cleary, W. J., and D. M. FitzGerald. 2003. "Tidal Inlet Response to Natural Sedimentation Processes and Dredging-Induced Tidal Prism Changes: Mason Inlet, North Carolina.” Journal of Coastal Research 19(4): 1018-1025.

Dabees, M. A., and N. C. Kraus. 2008. "Cumulative Effects of Channel and EBB Shoal Dredging on Inlet Evolution in Southwest Florida, USA." Proceedings of 31st International Conference on Coastal Engineering, 2303-2315. Hamburg, Germany.

Dastgheib, A. 2012. Long-Term Process-Based Morphological Modeling of Large Tidal Basins. Delft, Netherthands: Delft University of Technology.

Davies, J. L. 1964. “A Morphogenic Approach to World Shorelines.” Zeitschrift fur Geomorphologie 8: 127-142. Available from http://www.nmbl.org/cgi-bin/koha/opacdetail.pl?biblionumber $=38031 \&$ shelfbrowse itemnumber $=38453$.

Davis, R. A., and D. M. FitzGerald. 2004. Beaches and Coasts. Oxford: Blackwell Science Ltd.

Davis, R. A., and M. O. Hayes. 1984. "What is a Wave-dominated Coast?” Marine Geology 60(1-4): 313-329.

Davis Jr., R. A. 1994. West-Central Barrier System of Florida. New York: SpringerVerlag.

Davis, Jr., R. A., and J. C. Gibeaut. 1990. Historical Morphodynamics of Inlets in Florida: Models for Coastal Zone Planning. Gainesville, FL: Florida Sea Grant College.

de Beaumont, L. E. 1845. Septieme Lechon. Edited by P. Bertrand, 221-252. Paris, Libraire de la Societe Geologique de France.

De Swart, H. E., and J. T. Zimmermann. 2009. "Morphodynamics of Tidal Inlet Systems." Annual Review of Fluid Mechanics 41: 203-229.

Dean, R. G. 1973. "Heuristic Models of Sand Transport in the Surf Zone." Proceedings of Conference of Engineering Dynamics in the Surf Zone, 208-214. Sydney, Australia.

Dean, R. G. 1987. “Additional Sediment Input to the Nearshore Region.” Shore and Beach 55(3-4): 76-81. 
Dean, R. G. 1988. "Sediment Interaction at Modified Coastal Inlets: Processes and Policies." In D. G. Aubrey and L. Weishar, Hydrodynamics and Sediment Dynamics of Tidal Inlets, 412-454. New York: Springer-Verlag.

Dean, R. G. 1990. "Channel Entrances: Impacts on Coastal Erosion.” Proceedings of the 53rd Meeting of the Coastal Engineering Research Board, 51-53. CERC Final Report. Vicksburg, MS: Coastal Engineering Research Center.

Dean, R. G. 1993. “Terminal Structures at Ends of Littoral Systems.” Journal of Coastal Research Special Issue No. 18: 195-210.

Dean, R. G., and J. R. Houston. 2016. "Determining Shoreline Response to Sea Level Rise." Coastal Engineering 114(August 2016): 1-8.

Dean, R. G., and R. A. Dalrymple. 2002. Coastal Processes with Engineering Applications. Cambridge, UK: Cambridge University Press.

Dean, R. G., and P. A. Work. 1993. "Interaction of Navigation Entrances with Adjacent Shorelines.” Journal of Coastal Research 18: 91-110.

Dean, R. G., and T. L. Walton. 1975. "Sediment Transport Processes in the Vicinity of Inlets with Special Reference to Sand Trapping." Estuarine Research Volume II: Geology and Engineering, New York: Academic Press, Inc.

DiLorenzo, J. L. 1988. “The Overtide and Filtering Response of Small Inlet/Bay Systems.” In D. G. Aubrey and L. Weishar, Hydrodynamics and Sediment Dynamics of Tidal Inlets, 24-53. New York: Springer-Verlag.

Dissanayake, D. M., J. A. Roelvink, and M. van der Wegen. 2009. "Modeled Channel Patterns in a Schematized Tidal Inlet." Coastal Engineering 65(11-12); 10691083.

Dissanayake, D. M., R. Ranasinghe, J. A. Roelvink, and Z. B. Wang. 2011. "Process-based and Semi-Empirical Modeling Approaches on Tidal Inlet Evolution." Journal of Coastal Research Special Issue 64: 1013-1017.

Dombrowski, M. R., and A. J. Mehta. 1996. "Ebb Tidal Delta Evolution of Coastal Inlets." Proceedings of the 25th International Conference on Coastal Engineering, 32703283. New York: ASCE.

Douglas, S. S., A. Bobe, and Q. J. Chen. 2003. "The Amount of Sand Removed from America's Beaches by Engineering Works." Coastal Sediments 'o3. Clearwater, FL.

Duong, T. M., R. Ranasinghe, D. Walstra, and D. J. Roelvink. 2015. "Assessing Climate Change Impacts on the Stability of Small Tidal Inlet Systems: Why and How?” Earth-Science Review 154(March 2016): 369-380. http://dx.doi.org/10.1016/j.earscirev.2015.12.001.

Duong, T. M., R. Ranasinghe, D. Walstra, and D. J. Roelvink. 2017. “Assessing Climate Change Impacts on the Stability of Small Tidal Inlet Systems: Part 1 - Data Poor Environments.” Marine Geology 390 (1 August 2017): 331-346. http://dx.doi.org/10.1016/i.margeo.2017.05.008 
Elias, E. P., J. Cleveringa, M. C. Buijsman, J. A. Roelvink, and M. J. Stive. 2006. "Field and Model Data Analysis of Sand Transport Patterns in Texel Tidal Inlet (the Netherlands)." Coastal Engineering 53(5-6): 505-529.

Finkl, C. W. 2012. Pitfalls of Ebb-Shoal Mining. In J. A. Cooper, and O. H. Pilkey, Pitfalls of Shoreline Stabilization: Selected Case Studies, 37-52. Springer Science and Business Media.

Finkl, C. W., L. Benedet, J. L. Andrews, B. Suthard, and S. D. Locker. 2007. "Sediment Ridges on the West Florida Inner Continental Shelf: Sand Resources for Beach Nourishment.” Journal of Coastal Research 23(1): 143-159.

Finkl, C. W., Benedet, L., and T. Campbell. 2006. "Beach Nourishment Experience in the United States: Status and Trends in the 20th Century." Shore and Beach 74(2): 8-16.

FitzGerald, D. M. 1982. "Sediment Bypassing at Mixed Energy Tidal Inlets." Proceedings of the Eighteenth Coastal Engineering Conference, 1094-1118. New York: ASCE.

Fitzgerald, D. M. 1988. "Shoreline Erosional-Depositional Processes Associated with Tidal Inlets.” In D. Aubrey and L. Weishar, Hydrodynamics and Sediment Dynamics of Tidal Inlets. Vol. 29, 186-225. Lecture Notes on Coastal and Estuarine Studies. New York: Springer-Verlag.

FitzGerald, D. M. 1996. "Geomorphic Variability and Morphologic and Sedimentologic Controls on Tidal Inlets.” Journal of Coastal Research Special Issue 23: 47-71.

FitzGerald, D. M., I. V. Buynevich, and B. A. Argow. 2006. "Model of Tidal Inlet and Barrier Island Dynamics in a Regime of Accelerated Sea-Level Rise.” Journal of Coastal Research 2(Winter 2006): 789-795.

FitzGerald, D. M., M. S. Fenster, and B. A. Argow. 2008. "Coastal Impacts Due to SeaLevel Rise.” Annual Review of Earth and Planetary Sciences, 36(1): 601-647.

FitzGerald, D. M., N. C. Kraus, and E. B. Hands. 2000. Natural Mechanism of Sediment Bypassing at Tidal Inlets. ERDC/CHL CHETN-IV-30. Vicksburg, MS: U.S. Army Engineer Research and Development Center.

Fontolan, G., S. Pillon, F. Delli Quadri, and A. Bezzi. 2007. "Sediment Storage at Tidal Inlets in Northern Adriatic Lagoons: Ebb-Tidal Delta Morphodynamics, Conservation and Sand Use Strategies." Estuarine, Coastal and Shelf Science 75(1-2): 261-277. doi:10.1016/j.ecss.2007.02.029

French, J., H. Burningham, G. Thornhill, R. Whitehouse, and R. J. Nicholls. 2016. "Conceptualising and Mapping Coupled Estuary, Coast and Inner Shelf Sediment Systems.” Geomorphology 256(1): 17-35.

Garel, E., C. Sousa, and Ò. Ferreira. 2015. "Sand Bypass and Updrift Beach Evolution after Jetty Construction at an Ebb-Tidal Delta." Estuarine, Coastal and Shelf Science 167(Part A): 4-13. 
Garel, E., C. Sousa, Ò. Ferreira, and J. A. Morales. 2014. “Decadal Morphological Response of an Ebb-Tidal Delta and Down-Drift Beach to Artificial Breaching and Inlet Stabilisation." Geomorphology 216: 13-25. doi:10.1016/j.geomorph.2014.03.031

Hayes, M. O. 1975. "Morphology of Sand Accumulation in Estuaries." Estuarine Research Volume II: Geology and Engineering. New York: Academic Press.

Hayes, M. O. 1979. "Barrier Island Morphology as a Function of Tidal and Wave Regime." In S. Leatherman, Barrier Islands: From the Gulf of St. Lawrence to the Gulf of Mexico. New York: Academic Press.

Hayes, M. O. 1980. "General Morphology and Sediment Patterns in Tidal Inlets.” Sedimentary Geology 26(1-3): 139-156.

Hayes, M. O., and D. M. FitzGerald. 2013. "Origin, Evolution, and Classification of Tidal Inlets.” Journal of Coastal Research 14-33.

Hibma, A., Z. B. Wang, M. J. Stive, and H. J. de Vriend. 2008. "Modeling Impact of Dredging and Dumping in Ebb-Flood Channel Systems." Transactions of Tianjin University August 2008, 14(4): 271-281. Tianjin: Tran Tianjin University.

Hicks, D. M., and T. M. Hume. 1996. "Morphology and Size of Ebb Tidal Deltas at Natural Inlets on Open-sea and Pocket-bay Coasts, North Island, New Zealand.” Journal of Coastal Research 12(1): 47-63.

Hicks, D. M., and T. M. Hume. 1997. "Determining Sand Volumes and Bathymetric Change on an Ebb-Tidal Delta." Journal of Coastal Research 13(2): 407-416.

Hodgens, K. C., M. P. Neves, and L. S. Lillycrop. 2016. Northeast Florida Regional Sediment Management: Implementation Strategies and Recommendations for Nassau County and Duval County, Florida. ERDC/CHL TR-16-3. Vicksburg, MS: U.S. Army Engineer Research and Development Center.

Houston, J. R. 2017. "Shoreline Change in Response to Sea-Level Rise on Florida's West Coast.” Journal of Coastal Research 33(6): 1243-126o.

Houston, J. R., and R. G. Dean. 2016. "Erosional Impacts of Modified Inlets, Beach Encroachment, and Beach Nourishment on the East Coast of Florida." Journal of Coastal Research 32(2): 227-240.

Hoyt, J. H., and V. J. Henry, Jr. 1967. "Influence of Island Migration on Barrier-Island Sedimentation." Geological Society of America Bulletin 78(1): 77-86.

Jarrett, J. T. 1976. Tidal Prism-Inlet Area Relationships. GITI Report 3. Vicksburg, MS: U.S. Army Corps of Engineers, Coastal Engineering Research Center.

Kana, T. W., E. J. Hayter, and P. A. Work. 1999. "Mesoscale Sediment Transport at Southeastern U.S. Tidal Inlets: Conceptual Model Applicable to Mixed Energy Settings.” Journal of Coastal Research 14(2): 303-313. 
Kelley, J. T., and L. L. Brothers. 2009. "Camp Ellis, Maine: A Small Beach Community with a Big Problem...Its Jetty.” In J. T. Kelley, O. H. Pilkey, and J. A. Cooper, America's Most Vulnerable Coastal Communities, 1-20. GSA Special Papers 406. Boulder, CO: Geological Society of America.

Kraus, N. C. 2000. "Reservoir Model of Ebb-Tidal Shoal Evolution and Sand Bypassing." Journal of Waterway, Port, Coastal and Ocean Engineering 126(6): 305-313.

Kress, M. M., K. F. Touzinsky, E. A. Vuxton, B. Greenfeld, L. S. Lillycrop, and J. D. Rosati. 2016. "Alignment of USACE Civil Works Missions to Restore Habitat and Increase Environmental Resiliency.” Coastal Management 44(3): 193-208.

Larson, M., and N. C. Kraus. 2001. Estimation of Suspended Sediment Trapping Ratio for Channel Infilling and Bypassing. ERDC/CHL CHETN-IV-34. Vicksburg, MS: U.S. Army Engineer Research and Development Center.

Leatherman, S. P. 1988. "Beach Response Strategies to Accelerated Sea-Level Rise." Proceedings of the 2nd North American Conference on Preparing for Climate Change, 353-358. Washington, DC: The Climate Institute.

Legault, K. R., T. M. Beck, and J. A. Engle. 2012. "Influence of Inlet/Shoal Complex on Adjacent Shorelines via the Inlet Sink Method.” Proceedings of the International Conference on Coastal Engineering, 1-11. New York: ASCE.

Lillycrop, L. S. 2011. "Adaptive Management through Regional Sediment Management." Proceedings of the Western Dredging Association (WEDA XXXI) Technical Conference and Texas A\&M University (TAMU 42) Dredging Seminar. Nashville, TN.

Marine Minerals Program (BOEM). 2017. Building a National Offshore Sand Inventory. https://www.boem.gov/Building-a-National-Offshore-Sand-Inventory/

Mehta, A. J., and C. I. Montague. 1991. "Management of Sandy Inlets: Coastal and Environmental Engineering Imperatives.” Proceedings of Coastal Zone '91, 628642. New York: ASCE.

Mehta, A. J., M. R. Dombrowski, and P. T. Devine. 1996. "Role of Waves in Inlet Ebb Delta Growth and Some Research Needs Related to Site Selection for Delta Mining." Journal of Coastal Research Special Issue 23: 121-136.

Moore, L. J., J. H. List, S. J. Williams, and D. Stolper. 2010. "Complexities in Barrier Island Response to Sea Level Rise: Insights from Numerical Model Experiments, North Carolina Outer Banks. Earth Surface 115(F3).

Nahon, A., X. Bertin, A. B. Fortunato, and A. Oliveira. 2012. "Process-Based 2DH Morphodynamic Modeling of Tidal Inlets: A Comparison with Empirical Classifications and Theories." Marine Geology, vol. 291-294: 1-11.

Nicholls, R. J., A. Bradbury, H. Burningham, J. Dix, M. Ellis, J. R. French, and R. Whitehouse. 2012. "iCOASST -Integrating Coastal Sediment Systems." Coastal Engineering Proceedings 33. 
Oertel, G. F. 1988. "Processes of Sediment Exchange between Tidal Inlets, Ebb Deltas and Barrier Islands." In D. G. Aubrey, and L. Weishar, Hydrodynamics and Sediment Dynamics of Tidal Inlets, 297-318. New York: Springer-Verlag.

Oost, A. P., P. Hoekstra, A. Wiersma, B. Flemming, E. J. Lammerts, M. Pejrup, Z. B. Wang. 2012. "Barrier Island Management: Lessons from the Past and Directions for the Future." Ocean and Coastal Management 18-38.

Oost, A. P., Z. B. Wang, A. V. de Groot, L. A. Duren, and L. van der Valk. 2014. Preparing for Climate Change: A Research Framework on The Sediment-Sharing Systems of the Dutch, German and Danish Wadden Sea for the Development of an Adaptive Strategy for Flood Safety. Wageningen, the Netherlands: Deltares.

Pacheco, A., Ò. Ferreira, J. J. Williams, E. Garel, A. Vila-Concejo, and J. A. Dias. 2010. "Hydrodynamics and Equilibrium of a Multiple-inlet System." Marine Geology 274(1-4): 32-42.

Pettijohn, F. J., P. E. Potter, and R. Siever. 1988. Sand and Sandstone. New York:

Powell, M. A., R. J. Thieke, and A. J. Mehta. 2006. "Morphodynamic Relationships for Ebb and Flood Delta Volumes at Florida's Tidal Entrances.” Ocean Dynamics 56(3-4): 295-307.

Price, W. A. 1951. "Armstrong. Reduction of Maintenance by Proper Orientation of Ship Channels through Tidal Inlets.” Proceedings of Second Conference on Coastal Engineering, 243-255. Council on Wave Research, The Engineering Foundation.

Ranasinghe, R., and C. Pattiaratchi. 2003. "The Seasonal Closure of Tidal Inlets: Causes and Effects." Coastal Engineering 45(4): 601-627.

Ridderinkhof, W., H. E. de Swart, M. van der Vegt, and P. Hoekstra. 2014. "Influence of the Back-Barrier Basin Length on the Geometry of Ebb-Tidal Deltas." Ocean Dynamics 64: 1333-1348.

Ridderinkhof, W., H. E. de Sward, M. van der Vegt, and P. Hoekstra. 2016. "Modeling the Growth and Migration of Sandy Shoals on Ebb-Tidal Deltas." Journal of Geophysical Research: Earthy Surface 121(7): 1351-1372.

Roelvink, D. 2015. "Addressing Local and Global Sediment Imbalances: Coastal Sediments as Rare Minerals.” Proceedings of Coastal Sediments '15, 1-13. World Scientific Inc.

Rosati, J. D. 2005. “Concepts in Sediment Budgets.” Journal of Coastal Research 21(2): 307-322.

Rosati, J. D. 2009. Barrier Island Migration over a Consolidating Substrate. Baton Rouge, Louisiana: LSU Doctoral Dissertations, Louisiana State University.

Rosati, J. D., B. D. Carlson, J. E. Davis, and T. D. Smith. 2001. The Corps of Engineers National Regional Sediment Mangement Demonstration Program. (Rev. 2004). ERDC/CHL CHETN-XIV-1. Vicksburg, MS: U.S. Army Engineer Research and Development Center, Coastal and Hydraulics Laboratory. 
Rosati, J. D., and N. C. Kraus. 2009. "Model of Barrier Island Evolution at Decadal Scale." Coastal Engineering 2008 1: 2123-2135. World Scientific, Inc.

Rosati, J. D., R. G. Dean, and T. L. Walton. 2013. "The Modified Bruun Rule Extended for Landward Transport." Marine Geology 340: 71-81.

Schrader, M. H., E. C. Douglass, and L. S. Lillycrop. 2016. Regional Sediment Management Strategies for the Vicinity of St. Augustine Inlet, St. Johns County, Florida. ERDC/CL TR-16-12. Vicksburg, MS: U.S. Army Engineer Research and Development Center.

Schwartz, M. L. 1971. “The Multiple Causality of Barrier Islands.” Journal of Geology 79(1): 91-94.

Schwartz, M. L. 1973. Barrier Islands. Stroudsburg, PA: Dowden, Hutchinson and Ross, Inc.

Seabergh, W. C., and N. C. Kraus. 2003. "Progress in Management of Sediment Bypassing at Coastal Inlets: Natural Bypassing, Weir Jetties, Jetty Spurs, and Engineering Aids in Design." Coastal Engineering 45(4): 533-563.

Sexton, W. J., and M. O. Hayes. 1982. "Natural Bar-Bypassing of Sand at a Tidal Inlet." Proceedings of the Eighteenth Coastal Engineering Conference, 1479-1495. Cape Town, Republic of South Africa: ASCE.

Sha, L. P. 1989. "Sand Transport Patterns in the Ebb-tidal Delta off Texel Inlet, Wadden Sea, The Netherlands." Marine Geology 86(2-3): 137-154.

Sha, L. P., and J. H. Van den Berg. 1993. "Variation in Ebb-tidal Delta Geometry along the Coast of the Netherlands and the German Bight." Journal of Coastal Research 9(3): 730-746.

Siegle, E., D. A. Huntley, and M. A. Davidson. 2004. "Physical Controls on the Dynamics of Inlet Sandbar Systems.” Ocean Dynamics 54(3-4): 360-373.

Speer, P. E., and D. G. Aubrey. 1985. "A Study of Non-Linear Tidal Propagation in Shallow Inlet/Estuarine Systems. Part II: Theory.” Estuarine and Coastal Shelf Science 21(2): 207-224.

Stauble, D. K. 1998. Techniques for Measuring and Analyzing Inlet Ebb-Shoal Evolution. CETN-IV-13. Vicksburg, MS: U.S. Army Engineer Research and Development Center.

Stive, M. J., and Z. B. Wang. 2003. "Chapter 13: Morphodynamic Modeling of Tidal Basins and Coastal Inlets." Elsevier Oceanography Series. Amsterdam, Netherlands: Elsevier.

Stive, M. J., M. Capobianco, Z. B. Wang, P. Ruol, and M. C. Buijsman. 1998. "Morphodynamics of a Tidal Lagoon and the Adjacent Coast." Proceedings of the 8th Conference on Physics of Estuaries and Coastal Seas (PECS) 1996, 397-407. Balkema Rotterdam. 
Styles, R., M. E. Brown, K. E. Brutschè, H. Li, T. M. Beck, and A. Sànchez. 2016. "LongTerm Morphological Modeling of Barrier Island Tidal Inlets.” Journal of Marine Science and Engineering 4(65): 1-23.

Trudnack, M. E. 1997. Impacts on the Inlet-Beach System of Ebb Tidal Shoal Mining. Masters Thesis. Gainesville: University of Florida.

van de Kreeke, J., and R. L. Brouwer. 2017. Tidal Inlets. Cambridge, UK: Cambridge University Press.

van der Wegen, M. 2013. "Numerical Modeling of the Impact of Sea Level Rise on Tidal Basin Morphodynamics.” Journal of Geophysical Research: Earth Surface 118 (2): 447-460. doi:10.1002/jgrf.20034

Van Rijn, L. C. 2015. Sediment Import by Tidal Inlets: SEDBOX-Model for Tidal Inlets Marsdiep and Vlie, Wadden Sea, The Netherlands. leovanrijn-sediment.com. http://www.leovanrijn-sediment.com/papers/Sedimentimport2015.pdf

van Veen, J. 1950. "Ebb and Flood Channel Systems in the Netherlands Tidal Waters." Journal of the Royal Dutch Geographical Society Vol. 67, 303-325.

Walther, M. P., and B. D. Douglas. 1993. "Ebb Shoal Borrow Area Recovery.” Journal of Coastal Research SI 18: 211-223.

Walton, T. L., and W. D. Adams. 1976. Capacity of Inlet Outer Bars to Store Sand. Gainesville, FL: Coastal and Oceanographic Engineering Department, University of Florida.

Wang, H., L. Lin, and X. Wang. 1995. Laboratory Mobile Bed Model Studies on inlet Part II: Ebb Tidal Shoal Evolution Process. UFL/COEL-95/O21. Gainesville, FL: University of Florida.

Wang, Y.-H., C.-H. Wang, L.-Q. Tang, D.-B. Liu, C.-S. Guo, C.-J. Liu, and H.-M. Zhao. 2014. "Long-Term Morphological Response to Dredging Including Cut-acrossShoal in a Tidal Channel-Shoal System." Ocean Dynamics 64(12): 1831-1843.

Wang, Z. B., D. Van Maren, P. X. Ding, S. L. Yang, B. C. Van Prooijen, P. L. De Vet, and Q. He. 2015. "Human Impacts on Morphodynamic Thresholds in Estuarine Systems." Continental Shelf Research 111(part B): 174-183. doi:10.1016/j.csr.2015.08.009

Wang, Z. B., E. P. Elias, and C. Briere. 2007. Long-Term Interaction between the Dutch Coast and the Tidal Basins." Wageningen, the Netherlands: Deltares.

Wang, Z. B., P. Hoekstra, H. Burchard, H. Ridderinkhof, H. E. De Swart, and M. J. Stive. 2012. "Morphodynamics of the Wadden Sea and Its Barrier Island System." Ocean and Coastal Management 68: 39-57.

Wang, Z. B., T. Louters, and H. J. de Vriend. 1995. "Morphodynamic Modeling for a Tidal Inlet in the Wadden Sea." Marine Geology 126(1-4): 289-300.

Welsh, J. M., and W. J. Cleary. 2007. "Evolution of a Relocated Tidal Inlet: Mason Inlet, NC." Proceedings of Coastal Sediments '07. New Orleans: ASCE. 


\section{Unit Conversion Factors}

\begin{tabular}{|l|c|l|}
\hline Multiply & By & To Obtain \\
\hline cubic yard & 0.7645549 & cubic meters \\
\hline feet & 0.3048 & meters \\
\hline yards & 0.9144 & meters \\
\hline miles & .69 & kilometers \\
\hline
\end{tabular}




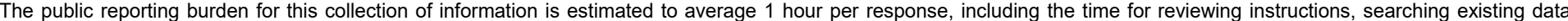

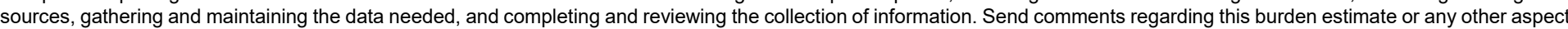

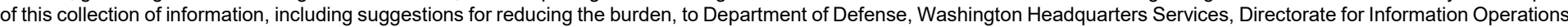

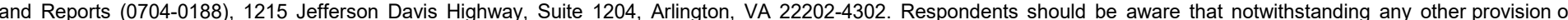
law, no person shall be subject to any penalty for failing to comply with a collection of information if it does not display a currently valid OMB control number. PLEASE DO NOT RETURN YOUR FORM TO THE ABOVE ADDRESS.

\begin{tabular}{l|l|l}
\hline 1. REPORT DATE & $\begin{array}{l}\text { 2. REPORT TYPE } \\
\text { Final Report }\end{array}$ & 3. DATES COVERED (FrOm - To) \\
August 2019 & Dinal
\end{tabular}

\section{TITLE AND SUBTITLE}

Review of Coastal Tidal Inlet Morphodynamics in the Context of Barrier-Inlet Sustainability 5a. CONTRACT NUMBER

5b. GRANT NUMBER

5c. PROGRAM ELEMENT NUMBER

5d. PROJECT NUMBER

U4352920

5e. TASK NUMBER

5f. WORK UNIT NUMBER

8. PERFORMING ORGANIZATION REPORT NUMBER

Coastal and Hydraulics Laboratory

U.S. Army Engineer Research and Development Center

3909 Halls Ferry Road

Vicksburg, MS 39180-6199

9. SPONSORING/MONITORING AGENCY NAME(S) AND ADDRESS(ES)

U.S. Army Engineer Research and Development Center

ERDC/CHL SR-19-6

3909 Halls Ferry Road

Vicksburg, MS 39180-6199

\section{SPONSOR/MONITOR'S ACRONYM(S) ERDC}

11. SPONSOR/MONITOR'S REPORT NUMBER(S)

\section{DISTRIBUTION/AVAILABILITY STATEMENT}

Approved for public release; distribution is unlimited.

\section{SUPPLEMENTARY NOTES}

\section{ABSTRACT}

This Coastal and Hydraulics Engineering special report is a general overview of coastal tidal inlet morphodynamics, sediment management practices, and barrier-inlet system sustainability at long-term, regional scales. The focus of coastal tidal inlet morphodynamics in this report is on the primary managed resource, coastal littoral sediments, which are the primary substrate for coastal barrier islands and tidal inlet sediment systems. Management practices concerned with sustainability are discussed with a temporal focus on planning horizons of 50 to 100 years. Special considerations are offered on how past coastal zone management has evolved the understanding of natural and anthropogenically modified geomorphic features and how perspectives have changed with regards to the sustainability of management practices for these sediment systems. Over longer timescales, such as centuries, the impacts of eustatic sealevel rise, climate change (e.g., storm intensity and frequency), long-term cross-shore and longshore sediment transport patterns, geologic isostacy and subsidence, and other important processes affect tidal inlet dynamics. Long-term studies conducted at regional spatial scales, including adjacent barriers and multiple inlets, are necessary to evaluate the cumulative effects of the aforementioned processes along with the effects of anthropogenic modifications, such as ebb-tidal delta mining and beach placement, to barrier-inlet sustainability.

\section{SUBJECT TERMS}

Barrier islands, Coastal zone management, Geomorphology, Inlets, Sedimentation and deposition, Sediment transport, Sustainability

\begin{tabular}{|l|c|l|l|}
\hline \multicolumn{3}{|l|}{ 16. SECURITY CLASSIFICATION OF: } & 17. LIMITATION OF \\
aBSTRACT \\
a. REPORT & b. ABSTRACT & c. THIS PAGE & \\
Unclassified & Unclassified & Unclassified & SAR \\
& & &
\end{tabular}

\section{NUMBER OF PAGES}

61 19a. NAME OF RESPONSIBLE PERSON

19b. TELEPHONE NUMBER (Include area code) 601-634-2603 